\title{
Muddy Waters: Inside the World Bank as It Struggled with the Narmada Irrigation and Resettlement Projects, Western India
}

\author{
Robert H. Wade
}

Narmada is a four letter word (Africa division chief, World Bank, 1995)

You believe that institutions change the world, Mr Bromley. I believe that infrastructure does. Come back in 20 years and we'll see who is right (Gabriel Tibor, chief of World Bank India Irrigation Division, late 1970s).

The important thing is that we have such a report, and can point to it. It will also be a very valuable source of facts and references. (Letter of half-thanks from Sardar Sarovar task manager to the author of the first environmental assessment of the project, 1988)

The Bank's resettlement policy is "an exaggerated response. The condition of equal livelihood in the new place is too stringent as a general rule. It is possible where land is abundant and where there is a good financial system (for example Argentina or even Mexico), but almost impossible - I would say impossible —in India and Bangladesh" (Ernest Stern, the first or second most powerful person in the World Bank from the late 1970s to his retirement in the mid 1990s, speaking in 1995).

If the Bank continued with the project "it would signal that no matter how egregious the situation, no matter how flawed the project, no matter how many policies have been violated, and no matter how clear the remedies prescribed, the Bank will go forward on its own terms"

This article is based on field work inside the World Bank (not on the ground in India) undertaken in 1995-96 for the World Bank History Project. It is an extended (three times longer) version of my account of Narmada in "Greening the Bank: the struggle over the environment, 1970-1995", in Devesh Kapur, John Lewis and Richard Webb (eds), 1997, The World Bank: Its First Half Century, Brookings, vol. 2. The latter publication had a small print run and neither Brookings nor the World Bank publicized it; indeed, for some years after publication the World Bank bookshop refused to stock it, on grounds that it was not published by the Bank. It has long been out of print. Since 1997 I have asked some 15 Executive Directors whether they know of the History, whether they have read any of it. Several said they had heard of it, one said he had read some of it. In Bank culture, the value placed on learning from the past is approximately zero. The present tense refers to the mid 1990s, except where the context makes clear otherwise.

\footnotetext{
R. H. Wade $(\bowtie)$

Department of International Development, London School of Economics, London, UK

e-mail: R.Wade@lse.ac.uk
} 
(Patrick Coady, US Executive Director, statement at the meeting of the Executive Board,

World Bank, 23 October 1992)

$$
\text { *** }
$$

The period since the Second World War has witnessed three global power shifts: one, from sovereign states relating to each other through balances of power, to interstate organizations which pool some sovereignty and enact collective preferences; two, from states to non-state organizations, including NGOs, enormously facilitated by the internet; and three, from West to East. The World Bank has been a microcosm of these shifts. This chapter describes the interplay between some of the agents: World Bank staff; World Bank top management; World Bank Executive Directors (representatives of member governments, who formally govern the Bank); Government of India and governments of states; Indian and international (mainly UK, US, Japanese) NGOs; and the US Congress. The context is the Narmada irrigation and resettlement projects in western India from the 1970s to the 1990s. The first of the projects (Sardar Sarovar) became the subject of a large-scale opposition movement, Indian and international, which ended up forcing the World Bank to take serious responsibility for resettlement and environmental sustainability in its projects worldwide, and to create an independent inspection facility to which people who consider their welfare net harmed by a World Bank-supported project can bring complaints direct to the Bank by-passing their national government.

Then in the mid 1980s the third set of actors-after staff and governments entered the game: NGOs, at first largely American and largely pursuing environmental objectives. They exercised leverage via their influence in the US Congress and its control of American finance for the Bank. They selected particular projects for scrutiny, aiming to reveal publicly that the projects were having seriously damaging effects not admitted by the Bank, and thereby to convince the Bank's shareholders that it needed reform.

The first project to attract serious criticism of the Bank from the US government, US NGOs, and the US public — the first "bomb"-was Polonoroeste, in northwest Brazil. ${ }^{1}$ At its core it involved paving a $1500 \mathrm{~km}$ road from the densely populated south central region into the sparsely populated Amazon. Beyond this, it intended to help establish the incomers in new farms and settlements, while also keeping them out of demarcated ecological and Amerindian zones. Starting in 1983 and continuing till 1987 US NGOs used Polonoroeste as their spearhead or trampoline for demanding changes in Bank policy. Suddenly the Bank found itself defined as the doer of harm and the teller of lies, and required to react to outsiders' ideas about how it should do its business. For an organization that had always prided itself on its service to humanity and unrivalled technical expertise, this was a bewildering experience. The Bank eventually suspended financial disbursements for the project in response to the NGO campaign and the evidence of environmental and social damage which the campaign unearthed-the first time in its history that it had suspended

\footnotetext{
${ }^{1}$ See Robert Wade, "Boulevard of broken dreams: inside the World Bank as it struggled with the Polonoroeste project in Brazil's Amazon", Brazilian J. of Political Economy, part 1, 36 (1), 2016, part 2, 36 (3) 2016.
} 
disbursements on such grounds. It resumed disbursements only after it was satisfied that the Brazilian government had made real progress on its commitments. Hence the Polonoroeste project has a seminal role in the story of how the Bank-and global norms more generally-moved from saying "We are a development organization and environment is for some other organization to deal with" to saying "Our mandate is environmentally and socially sustainable development"; and also in the interwoven story of how it moved from saying "We are accountable only to our shareholders (member governments), and NGOs can convey their views to us only through the relevant Executive Director on the Board" to saying "We are concerned to reach out to civil society organizations and learn from what they have to say".

As the Polonoroeste campaign was winding down in the late 1980s a second wave of attack on the Bank got underway. The "image" of this second wave was the Narmada projects in Northwest India.

The Narmada Valley Projects constitute a basin-wide, inter-state development scheme to harness the Narmada river, seen as one of India's last "unexploited" resources for hydropower and irrigation. Indian planners in the 1960s and 1970s envisaged four mega dams and hundreds of smaller dams being built along the Narmada river during the following half century or so, making it one of the largest water resource projects in the world. The first of the big dams, called Sardar Sarovar, would be as high as a 45 story building and over a kilometer long at the crest. Its reservoir would stretch for $200 \mathrm{~km}$, displacing some 40,000 households or 200,000 people. The canal at its head would be more than $200 \mathrm{~m}$ from one bank to the other, its network would extend for $75,000 \mathrm{~km}$ and irrigate almost two million hectares of arid land. ${ }^{2}$ The network would remove some portion of the land of 68,000 households. From the beginning the staff in the India Irrigation Division-the most powerful and prestigious division in the whole of the Bank, because it lent the most - saw the Narmada projects as the chance of a life-time to promote a paradigm change in Indian irrigation, from the prevailing late nineteenth century paradigm to a late twentieth century one geared towards the needs of complex agriculture. They saw themselves as innovators with a strong concern for what they called "the environment".

The transnational resistance to the Narmada projects began as a "bottom up" social movement (in contrast to Polonoroeste), led by Indian NGOs working in the

\footnotetext{
${ }^{2}$ This is the claim in the project documents. Indian irrigation canals normally irrigate a fraction of the planned irrigated area, there being political advantages to claiming a bigger area to be irrigated than is feasible. Politicians and engineers stand to earn many times their salaries by agreeing to extend the "planned" irrigated area to include hitherto excluded villages, regardless of feasibility. Also, inter-state water sharing agreements are based on "area to be irrigated", regardless of intensity of irrigation. Hence a project of 50,000 ha that planned to grow three crops of rice a year would get no more inter-state water than one of the same size that planned to grow only one crop of rice. Better to claim a very extensive irrigation and worry about broken promises later. See Wade, "On the sociology of irrigation statistics: How do we know the truth about canal performance?", Agricultural Administration, 19 (2), 1985, pp. 63-79. For an analysis of the Narmada projects as a case study of the inadequacies of traditional cost/benefit approaches to project planning see Jack Ruitenbeek and Cynthia Carier, "Evaluation of Narmada projects: An ecological economics perspective", Economic and Political Weekly (Bombay), 26 August, 1995, pp. 2138-45.
} 
Narmada valley. Their resistance sparked a campaign within India that drew unprecedented support from the middle-class public, among whom it signaled a profound shift away from Nehru's "hardware" notion of progress. The Indian campaign blossomed into the transnational alliance of NGOs that pulled in legislators from several Part I countries. (Part I refers to the richer, non-borrowing members of the World Bank, Part II to the poorer, borrowing members.)

Taking off just before the Bank's internal reorganization of 1987, the transnational campaign against Narmada stiffened Bank senior management's commitment to environmental assessment procedures and the creation of a large environmental complex. But the main effects came later. In response to years of pressure the Bank and Government of India canceled the Bank's involvement in the first of the big dams, Sardar Sarovar, in 1993 - the first time the Bank had canceled a loan anywhere in the world on environmental or social (as distinct from financial or procurement) grounds. Earlier an independent panel, appointed by the Bank, had reviewed the Sardar Sarovar project and the Bank's role in it, and reached conclusions very detrimental to the Bank. ${ }^{3}$

The momentum of the NGO campaign led the Bank to accede to the demands of US NGOs, the US Congress and the US and Dutch Executive Directors that the Bank establish, in 1993, a permanent "independent inspection panel" to which outside groups could bring complaints that they have been harmed by the Bank's failure to follow its own resettlement and environmental policies.

The Narmada campaign also accelerated the Bank's agreeing to a policy of freer disclosure of information about projects under preparation. And it helped to solidify the change in the Bank's stance towards NGOs from illegitimate to legitimate interlocutors. ${ }^{4}$ These important changes in the Bank's governance-making features new to the governance of any multilateral financial organization - were driven by the constantly boiling pot of Narmada. This chapter reveals the "underwear politics" of the project.

\section{Entry Conditions}

The Government of India (GOI) approached the Bank for help with the Narmada scheme in 1978, and in the same year the Bank sent a reconnaissance mission to determine an appropriate means for involvement. The Bank prepared the first stage

\footnotetext{
${ }^{3}$ Sardar Sarovar: The Report of the Independent Review, Ottawa: Resource Futures International Inc., 1992, also known as the Morse Commission Report. Cited as Independent Review, 1992.

${ }^{4}$ World Bank, "The World Bank's Partnership with Nongovernmental Organizations", Participation and NGO Group, Poverty and Social Policy Department, World Bank, Washington DC, May 1996. Lori Udall, "The World Bank and public accountability: has anything changed?", in Jonathan Fox and David Brown, The Struggle For Accountability: The World Bank, NGOs, and Grassroots Movements, MIT Press, Cambridge, chapter 11, 391-436.
} 
project (Sardar Sarovar dam and canals) in 1979-1983; appraised it in 1983-1984; the Board approved a loan and credit in March 1985 for \$450 million. ${ }^{5}$

On the Indian side several initial conditions shaped the trajectory of the project:

- The costs and benefits of Sardar Sarovar were spread very unequally between the three riparian states. Gujarat, where the dam was located, got the irrigation benefits, and the project had long been one of the top priorities of the Gujarat government. Madhya Pradesh (MP), where most of the reservoir was located, was home to most of the "oustees" (the convenient Indian-English word for those forced to resettle). Eighty percent of the 245 villages to be flooded were in MP. But MP got none of the irrigation benefits. MP's willingness to bear the costs of Sardar Sarovar was critical for the project going ahead. But it did not strongly want a project from which it received only a small share of the benefits in return for bearing most of the costs in flooded land and resettlement. It agreed to cooperate only in the expectation that the Bank would help fund a large upstream dam in MP from which it would derive most of the benefits. ${ }^{6}$ The third state, Maharashtra, had a small share of the costs and a smaller share of the benefits. Maharashtra had no strong interest in the project one way or the other. ${ }^{7}$

- There was no superordinate agency above the state governments to take authoritative decisions. Both water and resettlement are "state" subjects in the Indian federation. The mis-named Narmada Control Authority had neither control nor authority. It was only a coordination body, without a presence on the ground beyond the regional city. Hence the Bank had to deal with the state governments separately, and the state governments often disagreed. They could not even agree on a joint fisheries protection plan for the Narmada river.

\footnotetext{
${ }^{5}$ At the time of the Bank's appraisal this amounted to $18 \%$ of the cost of the dam and power sub-project and about $30 \%$ of the water delivery sub-project.

${ }^{6}$ The Bank's main leverage on MP came via its willingness to finance the upstream dam, Narmada Sagar (subsequently renamed Indira Sagar). Yet as the Bank later discovered, leverage via Narmada Sagar turned out to be much less than it thought. Political power in MP lies in the eastern part of the state, Narmada Sagar lies in the west. Within the west, power lies with rich landlords, many of whom did not want Narmada Sagar because it would flood their lands (and others did not want Sardar Sarovar for the same reason). In short, the politics of MP were such as to create no strong constituency for either Sardar Sarovar or Narmada Sagar. Cultural differences between the states added to the difficulties of cooperation. Gujarat is known as one of the most "progressive" states in India, next door MP as one of the most "backward". Gujarat is to Massachussets as MP is to Louisiana, it is said. Other differences fed in. Gujarat is one of India's smallest states (outside the northeast), and one of the wealthiest. MP is India's biggest state, the size of Germany and Austria combined; its 66 million people make it one of the biggest in population, bigger than all European states except Germany; and it is one of India's poorest states (14th of the 20 main states by per capita state domestic product). For much of the time between 1979 and 1993 the three states were run by different political parties, so they lacked even a common party bridge.

${ }^{7}$ The distribution of electrical power was meant to compensate. Under the terms of the tribunal award (clause VII) MP was to get $57 \%$ of the net power, Maharashtra $27 \%$, and Gujarat $16 \%$. But power is less valuable to politicians than irrigation in an economy of this type. Besides, since the power plant would stand in Gujarat, the other states could not be sure that Gujarat would comply with the stipulated shares.
} 
- Gujarat was well advanced in planning the scheme by 1978. It had even started work on the ground, that had then been halted by an inter-state water dispute, resolved by a federal tribunal in 1979 after 10 years of deliberation. When the Bank reconnaissance mission arrived the chief engineer for Gujarat dumped 18 volumes of plans on the table and said, "Here are our plans. We start tomorrow." $" 8$

On the Bank side, the new vice president for South Asia, David Hopper, an expert in Indian irrigation and agriculture, remained vice president during the critical first two-thirds of the Bank's involvement, from 1979 to 1987 . Under him the chief of the elite India Irrigation Division was Gabriel ("Gabby") Tibor, one of the Bank's longest serving and most charismatic division chiefs, a decorated Second World War veteran and Israeli irrigation engineer esteemed by colleagues as brash, innovative and hard-charging, and with a direct line-it was said-to Bank president Robert McNamara.

Hopper and Tibor agreed-as did the Secretary of Irrigation, Government of India-that the Bank had for too long been helping Indian engineers to perfect nineteenth century British engineering design instead of upgrading to late twentieth century design standards. They worried that if Gujarat's plans were not changed Sardar Sarovar would reflect a late nineteenth century solution to a problem that twentieth century technology had long solved. Gujarat's design gave priority to making water flow at a speed that was neither so slow as to deposit silt nor so fast as to cause erosion. In the twentieth century, reservoir management could handle the silt problem and canal lining could handle the erosion problem. A canal with reservoir and lining should therefore give priority to the higher levels of water control warranted by the more intensive and variegated agriculture of the late twentieth century. But Gujarat's designs did not reflect this.

For Hopper and Tibor, the inter-state tribunal's award in 1979 was what one of them described as "an evangelical moment". They wanted to seize the rare chance of Sardar Sarovar to make a beachhead of change in India's conservative irrigation establishment. Conversely, they thought Gujarat's existing plans would be a disaster in the making; the resulting canal would have insufficient water control to avoid extensive water logging and salinity, let alone support a variegated agriculture. Hence issues of seepage, drainage, and water control became central to the project's definition. In this limited sense the Bank, supported by the Indian irrigation secretary, gave great weight to "environmental" issues, and it baffled the Bank's project staff when the campaign later accused them of neglecting the environment.

However, the Gujarat government stoutly resisted any Bank-required delay. The Finance Minister told the Bank, "I have got 30 crores [300 million rupees] from the Assembly for the project. You want me to stop it now? How can I justify the delay?"

People both in the Bank and in India took for granted that, provided the water logging/salinity problems were taken care of and the engineering brought up to late

\footnotetext{
${ }^{8}$ Per Ljung, Project Officer, interview, March 12, 1996.
} 
twentieth century standards, the benefits would be so big that the costs did not have to be examined carefully. "If you drive out through the command area of Sardar Sarovar", said one of the project leaders on the Bank side, "you don't have to be a rocket scientist to see that the benefits of this project are absolutely huge".

India had no choice but to invest in big dams, hydro power and irrigation systems, they said. Some 15-20 million extra livelihoods had to be found each year in order to sustain the growing population. Some could be found in agriculture, provided there was irrigation and power. Some could be found in cities, provided there was water, sewerage, and power. Either water must be diverted from existing irrigationdisplacing existing farmers and making them the refugees of the future on a scale that would dwarf the numbers who had to move because of the reservoir-or additional dams and canals must be built. And the expanded hydro capacity would allow electricity to be provided without the additional air pollution of coal-fired power stations. The Sardar Sarovar hydro station would generate a more than $10 \%$ increase in power to India's Western Regional grid.

The assumption that benefits would vastly outweigh costs shaped what the planners paid attention to. Hardly any analysis lay behind the claim that 30 million people would benefit from improved domestic and industrial drinking water supply, for example. The existing situation was so bad that just about everyone could be assumed to benefit, said the project planners. Against a recommended Indian norm of 50-60 1 per person per day, and an average of about 201 a day for people living in the poorer parts of cities elsewhere in India with "adequate" overall water supply, the people living in the poorer parts of the cities of Gujarat were getting less than eight liters (two gallons) a day. So when a Bank resettlement specialist asked project staff in the late 1980s about the effect of the project on the drinking water supply of villages downstream of the dam, they responded impatiently, "We are bringing drinking water to $\mathrm{X}$ hundred villages in Gujarat that have never had reliable supplies before". The benefits to the new villages were so obviously greater than any possible loss to the downstream villages that the calculation did not have to be made. ${ }^{9}$

Indeed everything except the physical infrastructure was neglected. In 1980 a newly recruited Bank staff member with a degree in regional planning talked to several people in the India Irrigation Division about the Narmada projects, with a view to joining the division in order to work on regional development. He decided against after seeing that the division had little interest in matters beyond the water works.

Underlying this orientation was an assumption in the India Irrigation Division and in the Bank at large that infrastructure was the solution to development problems. When institutional economist Daniel Bromley gave a seminar on irrigation institutions at the Bank in the late 1970s Division Chief Tibor said impatiently, "You

\footnotetext{
${ }^{9}$ William Partridge, interview, March 10, 1995.
} 
believe that institutions change the world, Mr Bromley. I believe that infrastructure does. Come back in 20 years and we'll see who is right". ${ }^{10}$

The Bank's budgetary rules reinforced the assumption. The budget for project preparation related not to the complexity of the project, but to the size of the loan. A simple highway project would receive (roughly) the same project preparation budget as the same sized loan for a complex irrigation-and-hydro project. This apparently nonsensical practice reflected the difficulties of designing a more flexible budgetary system for the whole organization when the organization's bottom line was difficult to measure; and reflected more specifically President McNamara's drive to control the organization by means of simple coefficients linking inputs and outputs (not outcomes).

\section{Resettlement}

The national and international campaign against Narmada focused on resettlement more than environment. The resettlement problems that in the end forced the Bank out were inevitable as long as the project was not held either to the resettlement standards contained in the inter-state water tribunal's decision or to the standards of the Bank's own resettlement directive, adopted in 1980. Neither the South Asia regional staff nor any level of the Indian government gave priority to resettlement.

\footnotetext{
${ }^{10}$ I gave a seminar to the India Irrigation Division in 1981. The seminar was titled, "Institutional determinants of canal performance in India", and had been pressed upon the reluctant India Irrigation Division by people in the central Agriculture and Rural Development Department anxious to promote an institutional agenda as a complement to the engineering one. When the Irrigation people learned, the day before the seminar, that my "institutional determinants" included an elaborate system of irrigation corruption they panicked, and begged me to talk about other things. They said that the sociologist Michael Cernea was the Bank's corruption man, he took care of corruption issues, and if I wanted to talk about corruption I should do it under his auspices, not theirs. (Right up to 1995, when President Wolfenson arrived, "corruption" was a forbidden word across the Bank.) I persisted. I began the seminar by citing evidence of poor canal irrigation performance in India, and then started to describe the well-institutionalized corruption system as one of the main causes. Division Chief Tibor, seated in the central place, rose to his feet, made a harrumphing noise of disapproval,, and stormed out, slamming the door behind him. The others froze. Their discomfort worsened as I persisted in describing how the corruption system affected operation and maintenance. At the end the acting chair called for questions. Silence. Eventually a corpulent Pakistani irrigation engineer and Bank consultant spoke up. He wore two gold rings, a gold bracelet, and a Rolex watch. He protested that - though my account of large-scale irrigation corruption may apply to India - he had seen nothing beyond petty field staff corruption in his many years with the Pakistani irrigation service. With barely any more questions or comments the seminar came to a relieved end. One of the participants whispering as we left, "Methinks he (the Pakistani) doth protest too much". See Wade, "The system of political and administrative corruption: canal irrigation in India", Journal of Development Studies, v. 18 (3), 1982, 287-328; and "The market for public office: why the Indian state is not better at development", World Development, 13, 4, 1985, 467-97.
} 
The standard Bank line on resettlement worldwide had been, "It is the government's job to provide cleared land at the site of an infrastructure project. It is the government's job to decide how to treat the displaced". Then came the Sobradhinho incident in the late 1970s. Sobradhinho was a major dam in Brazil whose construction and reservoir entailed the involuntary resettlement of over 60,000 people. The Bank was helping to finance its construction. There was no plan to resettle the people. The dam was completed, the water began to rise, the people refused to move, their imminent submersion could not be ignored, the army was sent in to evict them. Some Bank staff tried to draw internal attention to the problem but were told that resettlement was a domestic matter. Church groups began to write letters to $\mathrm{McNa}$ mara, and McNamara was disturbed to find that the Bank had no resettlement policy. He indicated to the director of the central Agriculture and Rural Development (AGR) Department (Montague Yudelman) that the Bank should get something in place. Yudelman was already persuaded that the Bank needed a policy.

At the same time, Michael Cernea, the Bank's solitary sociologist, had become interested in forced resettlement (as distinct from resettlement of the voluntary kind, as in Malaysia's FELDA jungle settlements). ${ }^{11}$ Cernea worked for Yudelman. Now that McNamara was interested Yudelman boosted his support for what Cernea had already quietly started, a review of the Bank's experience with forced resettlement region by region. The review was to lead to resettlement policy guidelines for project officers.

Cernea was chief author of the Bank's operational policy manual statement (OMS) on involuntary resettlement, issued in February 1980. This was the first policy statement to be issued by an international development agency on the subject. It said, among other things, that the Bank required a resettlement plan whose "...main objective is to ensure that settlers are afforded opportunities to become established and economically self-sustaining in the shortest possible period, at living standards that at least match those before resettlement." 12 On the other hand, the Bank made clear that the cost for resettlement had to be born by local budgets; it would not lend for resettlement.

\footnotetext{
${ }^{11}$ Michael Cernea joined the Bank in 1974 as its first sociologist, having been professor of rural sociology in Romania. He is a Romanian refugee. Asked why he made such a crusade out of forced resettlement he replied that he considers himself an oustee.

In 1977 Cernea invited Thayer Scudder, one of the world's few resettlement experts and professor of anthropology at Caltech, to give a seminar in his newly launched sociology seminar series for Bank staff. They agreed the subject would be government-sponsored voluntary settlement schemes like Malaysia's FELDA and Indonesia's Transmigration. At the last minute Scudder changed the subject to something he was currently interested in, involuntary relocation, including Bank-financed dam projects like Kariba, Nigeria's Kainji, and Brazil's Sobradhinho. Cernea had not thought about involuntary settlement, and was intrigued by what Scudder said. With help from Scudder he began to review Bank projects region by region to see how forced resettlement had been handled. See Michael Cernea, "Social integration and population displacement: the contribution of social science", International Social Science Journal, v. 143, n.1, 1995.

${ }^{12}$ OMS 2.33, "Social issues associated with involuntary resettlement in Bank-financed projects", February 1980, para. 18.
} 
Then, as today, the Bank had many policy directives and guidelines. New ones landed on the project officers' desks every month or two. The art of the project officer was to figure out which ones mattered in the eyes of management. Around 1979 and 1980, when the resettlement directive was being prepared and introduced, resettlement attracted some attention inside the Bank, and plans were prepared for a number of projects. But for the next several years little happened as project officers saw that observance of the resettlement directive was not being monitored. It joined the long list of directives that could be ignored. These years of fading resettlement concern were the early years of Narmada.

The India Irrigation Division, its attention focused on redesigning the infrastructure to late twentieth century standards, ignored resettlement completely. Not till 1983, as Sardar Sarovar was being appraised, did Michael Cernea discover that the appraisal mission's terms of reference made no mention of resettlement. ${ }^{13}$ Yet the resettlement implications were enormous.

\footnotetext{
${ }^{13}$ Cernea had already lost a battle with the Indian Irrigation Division. He saw that a medium sized irrigation project in Gujarat had no resettlement plan, though many people were to be displaced. He protested to the project officer. The project officer ignored him, and Cernea threatened to bring the case to the attention of senior management. The project officer continued to ignore him, telling his colleagues, "We [the India Irrigation Division] will win, because they [senior management] need to disburse the [IDA] money". He was right. The Board approved the project flatly counter to the Bank's OMS on resettlement.

Cernea saw the documents for Sardar Sarovar in 1983 almost by accident. Not long before, he had moved offices and become the next-office neighbor of Fred Hotis, the Bank's irrigation advisor. Hotis had seen the earlier documents for Sardar Sarovar but had never thought of drawing them to the attention of Cernea, the resettlement expert. Cernea should have been involved, but it was not the irrigation advisor's job to involve him. One day in 1983 Hotis wandered into his new neighbor's office with the latest pile of Sardar Sarovar documents. They included the terms of reference of the Bank's appraisal mission. Hotis, as irrigation advisor, was required to clear the terms of reference of the appraisal mission before it left. And the Bank's OMS on resettlement said—by Cernea's careful design- "Overall design of the primary project and the proposed schedule for relocation should be completed before the start of the appraisal mission, making it possible to assess the various resettlement options and the stages for their implementation." "Have you seen these?", Hotis asked Cernea. Cernea saw that the terms of reference contained nothing about resettlement. He decided there and then to draw a line in the sand on Sardar Sarovar. His attention was extremely unwelcome to the project people, which was why they had gone to great lengths to keep the project out of his sight. Until then its preparation had gone smoothly enough for it to go to the Board on time, a hallmark of a successful Bank career.

When Cernea rang the division chief to ask about resettlement, the division chief (by then Tiber had retired and William Rodger, a British irrigation engineer, had replaced him) told him that the appraisal mission had already been in the field for a week-contravening both the OMS on resettlement and the requirement that the irrigation advisor sign off on the terms of reference before the appraisal mission set out (another example of the regional vice presidency beating the center). The division chief suggested that he would add resettlement to the already full agenda of the appraisal mission. The appraisal mission leader telegrammed back the news that the Indians said they would take care of resettlement. Cernea insisted that the OMS required the Bank to prepare the outlines of a resettlement plan before the appraisal could go forward. This led to a sharp discussion with the division chief. "Who are you, Michael, to tell me and the Government of India how to do resettlement? Don't you trust us?" Cernea replied that the issue was not trust. All he wanted was a resettlement plan as required by the Bank's OMS. Cernea said that he would have to advise his vice
} 
Cernea launched his own crusade to get the India Irrigation Division to pay attention to resettlement. Using his own Agriculture and Rural Development Department's budget he hired a well-known resettlement expert, Thayer Scudder, to investigate the resettlement situation. Scudder was "appalled" by what he found. ${ }^{14}$ Nothing had been done to inform villagers about resettlement options and rehabilitation packages. In both the federal government and the state governments he found virtually no-one dealing with resettlement.

All three states worried about the consequences of complying with the Bank's directive. The required level of compensation was very high: restoration to living standards that at least match those before resettlement, and "land-for-land" (compensation in land, not cash, for those forced to give up land, up to five acres, including those whose claim was customary rather than legal, these being mainly "tribals"). Compensation at this level in the Sardar Sarovar project, the governments feared, might set precedents for courts to apply retrospectively to the many hundreds of thousands of people already displaced by infrastructural projects, not to mention those to be displaced in future. MP was especially worried, because whereas Sardar Sarovar would be the last major irrigation and hydro project for Gujarat, for MP it was only the first in a line of Narmada projects within its borders. The federal government had limited leverage to make the states comply, because resettlement, like water, was a state subject.

The states began to play a game of "chicken", each aiming to do as little as possible for their own oustees in the hope that they would go elsewhere. MP, in particular, wanted its oustees to go to Gujarat. Under the terms of the water tribunal award Gujarat had to offer to accommodate oustees from other states and was meant to reimburse the other states for the resettlement costs of those who stayed behind. But the MP government had no confidence Gujarat would actually reimburse it. Maharashtra, too, sat on its hands until 1988-89. While playing this game all three states calculated that the Bank knew that insisting on its guidelines in Narmada would encourage people resettled in other Bank-financed projects in India, who got little compensation, to insist on the same. Surely the Bank would shrink from this Pandora's Box.

\footnotetext{
president that a resettlement plan did not exist and that the project was out of compliance with Bank directives. The division chief asked him not to. Cernea proposed a compromise. He would draft a memo to the vice president, he would copy it to the division chief, but he would delay sending it to the vice president. The division chief later rang him to tell him one of his staff was returning from Delhi shortly with a resettlement plan. Some weeks later, hearing nothing, Cernea rang the division chief. "Sorry, the photocopy machine in Delhi broke down. But the plan will come shortly." More weeks of delay. Then the project officer (Per Ljung) rang Cernea to say that a load of documents had arrived from Delhi, but no resettlement plan. Cernea said there would have to be a special "postappraisal" resettlement mission. The project officer said he had no budget. Cernea proposed that he would use his own department's budget to send a resettlement expert, Thayer Scudder, to investigate and make proposals. Snookered, the project officer reluctantly agreed. Such cat and mouse games were routine between experts in the central complex and the regional complexes of the Bank, and Cernea was a champion.

${ }^{14}$ Thayer Scudder, interview, 3 November, 1995.
} 
In this situation, Scudder recommended that the Bank get the state governments to agree on an "annual rolling plan" for resettlement instead of a comprehensive plan covering several years into the future. Cernea was very unhappy with this recommendation, seeing it as an escape hole. But Scudder saw it as only the beginning of a much bigger reorientation of thinking in India about development-project-induced resettlement, using Sardar Sarovar as the focus of a coalition to push for a national policy. The India Irrigation Division, on the other hand, was relieved by Scudder's recommendation, and henceforth tried to deal with consultant Scudder on resettlement matters rather than staff member Cernea.

In retrospect Scudder's "annual rolling plan" was a momentus recommendation. It encouraged the Bank to give away its biggest bargaining chip, project approval, in return for. . .very little. On the other hand, if Scudder had said, "Stop right here until a decent resettlement plan is ready", his report may have been quietly ignored and the project approved anyway. He made his recommendation in the knowledge that the Bank and the governments in India were not monolithic; he wanted to strengthen the hands of resettlement advocates inside the various organizations.

By the time of Board presentation in March 1985 the Bank had devoted just five resettlement-person-weeks to the examination of the social impacts of a project that forced the relocation of at least 200,000 people. But enough had been done by way of planning for the staff to assure the Board, with some truth, that "the measures embodied in the plan for resettlement and rehabilitation represented a significant advance over the practices of the past in India". ${ }^{15}$ However, neither the staff nor the supporting documents said that the "plan" was, in fact, no more than a diluted version of the resettlement principles enunciated in the inter-state water tribunal's award of 1979. Or that the tribunal's award, being focused on principles of watersharing, did not claim to set out comprehensive resettlement principles, and failed to mention some of the most difficult issues. ${ }^{16}$ It fell far short of what constituted a "plan" in the Bank's own resettlement directive. The staff also did not say that

\footnotetext{
${ }^{15}$ Summary of discussions at the meeting of the Executive Directors of the Bank and IDA, March 7, 1985.

${ }^{16}$ The tribunal award was nevertheless important in resettlement thinking. It established for the first time in India the principle of land-for-land (as distinct from cash-for-land) and indirectly shifted thinking in the Bank toward the same principle.

The Independent Review chastises the Bank for ignoring "tribals". Bank policy for involuntary resettlement makes special provision for tribal people, and by the time of Sardar Sarovar appraisal the Bank had an Operational Manual Statement setting out these provisions (OMS No.2.34, Tribal Peoples in Bank Financed Projects, February 1982). According to Indian census data, a large proportion (perhaps half) of the dam and reservoir oustees are tribals, yet the project appraisal documents and the loan agreement make no mention of tribals. I do not emphasize this omission. The OMS on tribals, written by Robert Goodland in connection with Polonoroeste, has scant application to most of India. The poorest and most vulnerable people in the Narmada area are as likely to be scheduled castes as tribals. There seems to be no strong justification for dividing very poor people into different social categories and giving one of them, tribals, special attention. All Narmada's poor people were being treated as detritus, not just tribals.
} 
India's practices of the past were generally disastrous, and fell far short of India's own legal requirements.

Hence, for all that Sardar Sarovar was intended in the Bank to be the spearhead of a new irrigation paradigm in Indian irrigation the new paradigm did not, apparently, include resettlement. That was a "social" issue. David Hopper, the vice president, was forthright in saying that resettlement was peripheral. "You can't make omelets without breaking eggs", he kept saying dismissively.

\section{Resettlement After Project Approval}

The Bank declared the Sardar Sarovar loan effective in early 1986. But then India's Ministry of Environment and Forests refused to clear the project for environmental reasons. This caused a hiatus in the project until the ministry issued a conditional clearance in 1987. In that year a resettlement mission went out to see what progress had been made in the meantime. It found that those villagers who had already been moved to make way for the dam were still languishing in resettlement villages on sterile land without even rudimentary infrastructure. On its return it recommended that the Bank threaten India with cancellation on grounds of its non-compliance with the resettlement agreement. ${ }^{17}$ Weeks later the Bank's reorganization of June 1987 hit, and the main proponent of the cancellation threat, the project's lawyer, Carlos Escudero, by then a resettlement champion, was moved to work on banking in Indonesia, despite his three requests to be allowed to continue with Narmada. His transfer was a victory for the India Irrigation Division.

Yet by this time the wider resettlement climate in the Bank was changing. The Bank's senior management, Ernest Stern in particular (number two in the hierarchy), signaled that the Bank had to take resettlement seriously - thanks both to an internal review by Michael Cernea showing the Bank's poor resettlement record worldwide $^{18}$ and to the escalating Narmada campaign focused on resettlement. Like it or

\footnotetext{
${ }^{17}$ Formally, the recommendation was for suspension followed by cancellation, since Bank procedures require that suspension precede cancellation.

${ }^{18}$ World Bank, Agriculture and Rural Development Department, "Involuntary resettlement in Bank-assisted projects: a review of the applications of Bank policies and procedures in FY197985 projects", February 1986. The background is as follows. In 1985 Cernea, supported by AGR Director Yudelman, began a review of Bank resettlement work since the directive of 1980 . He found that most Bank projects with significant resettlement were out of compliance, and that three quarters of the appraisals of projects with serious resettlement implications had been done by missions that contained not a single resettlement expert. He informed his vice president that many Bank projects could explode at any moment because of neglected resettlement. When the report landed on the desk of Ernest Stern, the senior vice president for operations, he was furious. "Why weren't these things flagged when these projects came to the Loan Committee?", he demanded. "Who was asleep at the switch?" The regional vice presidents pointed the finger at Cernea. Cernea went back into his carefully maintained files, and produced a sheaf of memos to show how he and a few other staff had tried to raise the resettlement issues without success. Stern thereafter gave his
} 
not, the India Department therefore began to formulate what it called an "incremental" approach to Narmada resettlement, one that would avoid the need for a comprehensive (and time-consuming) plan. Several years remained before large numbers of people would have to be moved, which gave time for steady pressure on the state governments to yield actions that would in the end constitute compliance with the Bank's directive.

The incremental approach had drawbacks. First, it gave an excuse for never collecting the data necessary to get a clear overview of the scale of the resettlement problem. Second, as news spread of the compensation possibilities adult sons and anyone else who might make a claim raced back from all across India. So not only were there no good figures about the number of oustees at the start, the number claiming oustee status kept growing. Third, from the Indian government standpoint, the incremental approach looked like a constant shifting of goal posts, a continual imposition of new targets. On the other hand, the Bank's own resettlement expertsby now several in number-tended to see the incremental approach as an unscrupulous way for the Bank always to be able to declare "progress". One of them said, "If you keep lowering the goal posts eventually people can score touchdowns no matter what they do".

By the late 1980s the Bank was devoting serious resources to resettlement. First in Gujarat and then in Maharashtra some progress began to be made on the ground, though hardly enough to lance the gathering international storm. What caused the turnaround? In 1988, with the international campaign in full swing, a high-level resettlement mission went to India led by Senior Vice President for Operations Moeen Qureshi, the first time a senior manager had involved himself directly. ${ }^{19}$ He was briefed intensively by NGOs in Washington DC before he left. (In the 1987 reorganization Qureshi replaced Stern and Stern was moved to be head of the financial complex. Had he remained in charge of operations these meetings with NGOs would probably not have occurred.) On his return Qureshi again had intensive private discussions with NGO leaders about what to do, including a two hour meeting with Oxfam's John Clark with only the acting director of the India Department present. They discussed a set of benchmark actions by the Indian authorities which would justify continued Bank involvement. In November Qureshi wrote a strong letter to the Chief Minister of MP imposing a series of resettlement-related conditions to be met by December 1988 and March 1989, and threatening to suspend disbursements in March 1989 if the conditions were not met.

In April 1989 another resettlement mission went out partly to monitor the actions called for in Qureshi's letter. Thayer Scudder joined this mission. He found the state governments still playing the game of chicken, making their own resettlement sites

\footnotetext{
support to resettlement. Cernea recommended that the Bank protect itself from public attack by issuing a follow-up to the 1980 OMS in the form of an Operational Policy Note, under his central vice president's signature, calling for observance of the original OMS. The vice president agreed, and the Operational Policy Note came out in 1986.

${ }^{19}$ Earlier in 1988 President Conable had visited India and met with Narmada activists to hear their story, but he was not operationally involved.
} 
as unattractive as possible. The people in the early resettlement sites, who had been moved to make way for the dam itself, still languished, years later, in the tin shacks erected for them on their arrival. The shacks turned into ovens in the summer heat, and the settlements still lacked basic infrastructure such as wells. ${ }^{20}$

At the end Scudder wrote a long report to the head of the Delhi office's Agricultural Unit. He said, "In comparing the August 1984/September 1985 situation with the situation today, I believe there has been a serious deterioration". ${ }^{21} \mathrm{He}$ went on to call for permanent or temporary termination of World Bank disbursements. The head of the Delhi office's Agricultural Unit (who had traveled with him to some of the existing resettlement sites) incorporated bits of Scudder's report into the overall mission report but reversed Scudder's conclusions-and then made Scudder joint author of the overall report. He emphasised the progress being made at the level of policy and organizational arrangements (such as the establishment of land purchase committees and grievance procedures). He recommended that in light of the progress the threat of suspension in Qureshi's letter be withdrawn.

When Scudder saw the report he was appalled, and insisted that his name be removed. Then Scudder's own confidential report to the head of the Agricultural Unit mysteriously leaked to the Indian press, causing a sensation. Inside the Bank a witch hunt began to find the leaker. The head of the Agricultural Unit in the Bank's Delhi office was shocked to learn that even he was under suspicion, such was the paranoia. In the event, the Bank told Government of India that it was satisfied with progress on the ground, and withdrew the threat of suspension.

Soon afterwards it was discovered, to the embarrassment of the Bank's Legal Department, that the Forestry Act of India and the Ministry of Environment and Forests' conditional clearance given in 1987 both explicitly excluded the use of forest land for resettlement purposes, while the loan agreements with each of the three states specifically included forest land for resettlement. ${ }^{22}$ Eventually, after more negotiations, a threat of Bank suspension, and the intervention of Prime Minister Rajiv Ghandi, Maharashtra agreed to waive the exclusion of forest land, which opened the way to 3000 oustee families being resettled. The Bank regarded this as the breakthrough it had been waiting for.

Yet deep resistance remained in the state governments and the Narmada Control Authority to the idea of the project being responsible for resettlement. Within the elite Indian Administrative Service, resettlement continued to be at the bottom of the prestige hierarchy. A posting as Resettlement Officer was a punishment.

\footnotetext{
${ }^{20}$ See Catherine Caufield, Masters of Illusion: The World Bank and the Poverty of Nations, Macmillan, 1997, especially chapter 1.

${ }^{21}$ Thayer Scudder, memorandum to Michael Baxter, April 29, 1989, emphasis added.

${ }^{22}$ The Bank's Development Credit Agreement with Government of India, May 19, 1985, says (sec.3.02), "the Borrower shall take. . .all such action as shall be necessary, including. . .the provision of forest land" for resettlement purposes. But the Ministry of Environment and Forests' clearance for Sardar Sarovar explicitly prohibits use of forest land for resettlement. The contradiction was not spotted—or not acknowledged—until the Maharashtra issue in 1989.
} 
The unconcern with resettlement, even in Gujarat as late as 1992, can be seen in a submission by the Gujarat government to the independent review panel on the subject of the canal oustees (those whose land had to be acquired as right-of-way for the canal). The submission said that the Bank's requirements (land for land) were excessively stringent, that the Land Acquisition Act of 1894 gave adequate protection, and that in any case, "For such a large irrigation project, which is to benefit the community at large, the farmers have always been ready for slight sacrifice". 23

The attitude on the Indian side was colored by the fact that about half of the oustees were classified as "tribals", who receive particular disparagement from caste Indians. The chief engineer of the project raged at Bank staff, "Why are you are so concerned about tribals? What they need is sterilization!"24

\section{Environment}

Long before the Tribunal award the Gujarat government had already chosen the dam site and the height of the dam, and had already started to build the foundations before being forced to stop by the inter-state water dispute. Experts in environmental assessment agree that the site and height of a dam are the two main variables determining its environmental impacts. With these decisions Gujarat locked in the parameters of the dam's environmental impacts before the Bank became involved.

The whole thrust of the Bank in the first several years was to redesign Gujarat's plans so as to make the dam and canal less likely to cause water logging and salinity. In that limited sense environment was central, though not called as such. Everything else that we might call environmental was neglected up to and beyond project approval. Robert Goodland, from the Bank's tiny, mostly "shop window", Office of Environmental Affairs, elbowed himself into two early missions. He mapped out a series of environmental studies required before a proper environmental assessment could be made. After these two visits the India Irrigation Division refused to allow him anywhere near the project again, and without its permission he could not go. The absence of environment work was even less of an issue inside the Bank than was resettlement, partly because, unlike resettlement, environmental assessments were not covered by even a weak Bank directive before 1984, and because the Office of Environmental Affairs was considerably weaker in the Bank's power structure than

\footnotetext{
${ }^{23}$ Cited in Independent Review, p. 206, emphasis added.

${ }^{24}$ A similar spirit was expressed by the education secretary for Uttar Pradesh in the early 1990s. He gave endless excuses as to why the state government had not undertaken the planning for the use of a large grant from a UN organization for primary schooling. Eventually the head of the Delhi office banged the table in exasperation and said, "Please, sir, tell me what is really going on here." He looked at her and said, "If we provide education for the children of poor people, where will our children get jobs?" Those who like to bracket India with China as emerging world powers would be wise to weigh the attitude of the chief engineer and the education secretary.
} 
the Agriculture and Rural Development Department, where Cernea the resettlement champion sat.

At the time of approval in 1985 there was virtually no knowledge of: the state of forest cover in the valley, the environmental impact of forest loss (for example, on siltation in the reservoir), the impact of the project on downstream communities (for example, drinking water and fisheries), the effects on run-off into the sea and the risk of salt-water intrusion, the impact on groundwater, the impact of resettlement on the environment (including on the demand and supply of fuelwood, central to the success of resettlement).

However, a dated covenant did go into the loan agreement with each of the states saying that an environmental workplan would be prepared by December 1985 (after approval but before effectiveness). But none of the documentation indicated what constituted an "environmental workplan", beyond a few sentences calling for suitable training for staff and studies of fish, forest, wildlife, and public health. Nor did any of the Bank's project documentation (including the Staff Appraisal Report) mention that the project had not yet received clearance from the Ministry of Environment and Forests, which was required by both Bank and Government of India's rules of project approval. Earlier, in 1983, India's environment agency (then located within the Ministry of Science and Technology) had refused to clear the project because of lack of information about environmental aspects, and the refusal still stood when the loan was approved. ${ }^{25}$

Nor did the documentation reveal that the calculations of the expected hydrological, irrigation and power performance of Sardar Sarovar assumed the existence of the Narmada Sagar dam upstream to provide the required degree of water control. Either the benefits were greatly overstated, or the Bank was implicitly committing itself to a much bigger investment (Sardar Sarovar plus Narmada Sagar) than the documents said. A 1992 Bank study found that without the second dam the power production of Sardar Sarovar would be $25 \%$ less than planned and the irrigated area $30 \%$ less. $^{26}$ This was omitted from the Sardar Sarovar documentation, though well known to the staff. They connived at the pulling of wool over eyes.

At the Board meeting in 1985 to approve the project only one Executive Director raised worries about potential environmental problems. The staff replied that "although a full environmental impact assessment had not been completed, a comprehensive first-stage assessment had been conducted by the University of

\footnotetext{
${ }^{25}$ This exposed a routine breach of Bank procedures that had been going on for years in Bank-India dealings. The Bank's rules require that it receive a communication from the borrower stating its approval of the negotiated legal documents before the Bank brings the project to the Board (BP 10.00 annex J, 1994, which repeats a directive in force since long before Sardar Sarovar). Such documentation was not being received from India for any project. The government of India argued that the Bank could take the fact that it sent a negotiating team as sufficient evidence that the project had all the necessary clearances within India. The Bank had long acquiesced as part of its special relationship with India, on whom it depended heavily for borrowings and interest repayments.

${ }^{26}$ Independent Review, p. 250 .
} 
Baroda and then examined by members of the World Bank appraisal team. That study covered public health, flora and fauna, fisheries, wildlife and archaeology and had determined that there were no endangered species in the area". ${ }^{27}$ This so-called "comprehensive first-stage assessment" was in fact a short, general document dating from the early 1980s, that could not remotely qualify as an environmental assessment. (Robert Goodland had seen this document on his second visit, and described it as "high-school-level".) Notice how the staff covered themselves by describing it as "first-stage"; and they gave the impression that the environmental situation contained nothing to worry about by reporting as the sole finding the absence of endangered species in the area. The uncurious Board fell for it.

Why was the project declared effective when the dated covenant requiring an environmental workplan had apparently not been met? Because what constituted an "environmental workplan" was unclear. The project's lawyer, with no guidance, decided that the Indian side's short list of planned studies constituted a "plan". He signed off.

The India Department's position on environmental questions was based not only on the wish to avoid delays. It said that the likely environmental impacts simply could not be estimated so long in advance. What was needed was a mechanism to monitor environmental effects as the project developed and take mitigating actions as the effects showed up. It considered as mistaken the whole idea of requiring an environmental action plan of the kind that the Bank's recently introduced (1984) OMS on environmental aspects of projects could be taken to call for. Its interpretation of the phrase "environmental workplan" as meaning a list of forthcoming studies constituted the triumph of substance over process in its eyes.

\section{Environment After Approval}

In 1987 India's recently formed Ministry of Environment and Forests granted a provisional clearance on condition that the three state governments complete several environmental studies by 1989 . The studies were tied to the construction schedule, so the compromise became known as the pari passu principle: environmental impacts were to be determined and mitigation measures put in place in concert with construction.

Also in 1987 the Bank took the first step toward a proper environmental assessment. The India Department hired as a consultant a California water expert with much experience of environmental assessments. He worked in the Bank and in India for a year and a half. But in the meantime the person who had commissioned him moved out of the project team, leaving him without an internal patron. Other members of the India Department regarded him with indifference or suspicion, as

\footnotetext{
${ }^{27}$ Summary of discussions at the meeting of the Executive Directors of the Bank and the IDA, March 7, 1985, para. 14, emphasis added.
} 
also did the environmental specialists in the newly created Asia regional environmental division (who had no hand in his recruitment).

He found the whole atmosphere poisonous. When he presented the draft in 1988 the project officer skimmed it and looked at him with dismay, and protested, "We don't have a budget to deal with these things". Of the many people sent copies, only two replied, one of them being the person who had originally commissioned him, the other being the post-reorganization task manager to whom he was working. The latter sent him a note of thanks saying, "The important thing is that we have such a report, and can point to it. It will also be a very valuable source of facts and references." ${ }^{28}$ The implication was that the report satisfied a formal requirement but did not entail any particular follow-up. Having identified many areas on which more analysis was needed the consultant wanted to continue to work on the environmental assessment, but nobody would hire him. He later commented, "It is amazing how hard it was to find money for such 'peripherals' in a multibillion dollar project!"

So his report, running to 300 pages, died. ${ }^{29}$ However, once the regional environmental divisions (REDs) were formed in 1987 one person in the Asia RED became the "environmental contact person" for Narmada. He was a professional biologist who had headed the Asian Development Bank's small environmental unit before joining the Bank. ${ }^{30} \mathrm{He}$ set about persuading the India Department to commit itself to helping the state governments prepare an environmental workplan. The Canadian aid organization, CIDA, promised money.

In the end, nothing happened-again. The Canadians backed away in the face of the political heat enveloping the project. The project authorities and state governments remained unsympathetic, claiming that quite enough was known about the environment; and the state governments refused to cooperate with each other. The India Department thought that the Asia RED contact person should himself solve the problem of the missing environmental workplan. Instead he told the department that hardly anything had been done at the Indian end, that every piece of environmental data was suspect, and that recommendations about mitigation could not be made until detailed (and time-consuming) studies had been made. When they pressed him on what exactly the environmental workplan or environmental assessment would have to consist of, his replies were, in the word of the South Asia vice president, "gibberish". All the environment contact person did, in their view, was to produce unhelpful back-to-office reports like:

October 1988: "It is evident that many of the environmental components of the project are in disarray... It is still unclear ... what the environmental and social consequences of the projects might be....Opportunities are being squandered."

\footnotetext{
${ }^{28}$ Christoph Diewald to Don Levenhagen, 12 December 1988, emphasis in original. Interviews with Don Levenhagen, 6 and 8 November, 1995.

${ }^{29}$ Overview Environment Assessment-Sardar Sarovar and Narmada Sagar Projects-Narmada River Basin, India, March, 1989, World Bank.

${ }^{30}$ Colin Rees, one of the team of three that drew up the Bank's environmental assessment OD.
} 
June 1991: "The Narmada Control Authority currently seems to have only marginal impact on the execution of the environmental studies and action plans, and beyond occasional meetings, has done little to help integrate the studies and plans with engineering planning and implementation". ${ }^{31}$

Worse, he began to call for changes in the dam so as to reduce the damage to estuary fisheries, and even to echo demands from Indian and international NGOs that the environment plan should examine alternatives to the basic design of the Narmada projects. This made the India Department apoplectic.

In early 1992 the consultant who had written the first preliminary environmental assessment several years before was asked to make a short update. He found the whole project disintegrating, with relations between people and organizations infused by poison all around. Most dispiriting, he found that almost none of the follow-up work that the states' environmental agencies had agreed to do in discussions with him in 1987-88 had actually been done; nor had the Bank put them under any pressure to do it.

Later, in 1992, while the independent review panel was at work, the Bank's India staff ranked Sardar Sarovar as having only "moderate" environmental problems. In the covering memorandum for the staff's report environmental problems are not even mentioned as possible obstacles to the planned acceleration in the construction schedule (though resettlement and health problems are so identified). Yet the provisional clearance granted by India's Ministry of Environment and Forests in 1987 had been conditional upon the completion of eight specific environmental studies by 1989 . None had been completed by that time, and virtually none had been completed by 1992 when the Bank rated the project's environmental aspects as having only "moderate" problems. Nor was a plausible environmental workplan ready, 5 years after the start of dam construction above the foundations. ${ }^{32}$

\section{External Pressure}

In the late 1970s a community health organization called ARCH was working in the tribal belt of Gujarat, that covered the dam site. ${ }^{33}$ When construction work on the foundations of the Sardar Sarovar dam began (initiated by the Gujarat government before the inter-state tribunal award) ARCH discovered that villagers had not been informed about the project. The future oustees only learned they were going to be evicted when government surveyors drove into the villages to mark out the future water line of the reservoir, below which loggers could strip the timber. When ARCH heard the World Bank was involved it asked its main foreign funder, UK-based

\footnotetext{
${ }^{31}$ Independent Review, p. 228.

${ }^{32} \mathrm{Health}$ aspects of the project were almost completely ignored throughout, by both the Bank and India, for all the obvious dangers of malaria and schistosomiasis.

${ }^{33}$ The full name was ARCH-Vahini, headed by Anil Patel.
} 
Oxfam, for help. The head of Oxfam's campaign programs, John Clark, visited the Narmada valley in 1982 and decided to take up the project. ${ }^{34}$ Oxfam began to organize a letter writing campaign to the Bank and to UK members of parliament, yielding hundreds of letters, to which the Bank sent a standard reply of the "You can be sure your concerns are receiving our full attention" kind. (At this time communication between Oxfam in Oxford, UK, and $\mathrm{ARCH}$ headquarters in the valley was by letter, a minimum of 3 weeks round trip if a motorcycle was standing by to take the letter from the regional town to the headquarters.) In 1985 Oxfam orchestrated the creation of an international Narmada campaign, involving NGOs from many countries, to press for better resettlement. ${ }^{35}$

Meanwhile another local NGO had come to prominence in the Narmada valley, later called the Narmada Bachao Andolan (NBA), translated as Save the Narmada Movement. It was led by a fiery, charismatic social worker named Medha Patkar, seen by some as a latter-day Gandhi figure. Patkar linked up with the US-based Environmental Defense Fund (EDF). There a new recruit, Lori Udall, took up the Narmada cause full time, encouraged by EDF's seasoned Bank campaigner, Bruce Rich (moved from the Natural Resources Defense Council). ${ }^{36}$ Leadership in the

\footnotetext{
${ }^{34}$ Ironically, the very lack of controversy about Narmada at the time recommended it to Oxfam. The organization had been thinking of taking up another big dam project in India for inclusion in its portfolio of projects for the "Real Aid" campaign. But the other project was already embroiled in controversy, and Oxfam's Delhi office dissuaded John Clark from taking it on, so as not to be seen taking sides against Government of India. Oxfam, as an operational agency with projects of its own on the ground, had to be careful about opposing the government. So Narmada was included within Oxfam's on-going Real Aid campaign for poverty-focused aid, one of about 12 projects targeted for public attention. Gradually Narmada began to catch on with the Oxfam-supporting public in Britain, more so than the other projects in the campaign, partly due to the British romance with "tribals" and the fact that tribals were being displaced without compensation (having no formal title to their land).

${ }^{35}$ By 1984 John Clark and Oxfam had good covert contacts with the resettlement specialist and a few staff in the India Department. They monitored the status of resettlement as the project moved towards loan approval. They saw that their letter writing campaign was not having much effect. In early 1985 the Environment Liason Center, the United Nations Environment Program offshoot dealing with NGOs, organized an international conference on environment and development in Nairobi. Clark lead a workshop on Narmada resettlement. Afterwards he invited all the participating NGOs to campaign jointly for changes in Narmada. This marked the birth of the international Narmada Campaign. The campaign accelerated after loan approval, when it became clear that the agreement implicitly accepted that those entitled to compensation included only those with legal title, which meant that most of the tribals, who accounted for a majority of those to be displaced, would not be compensated (in practice, neither would many with legal title).

${ }^{36}$ Bruce Rich, in charge of the Environmental Defense Fund's international program and a leader of the Polonoroeste campaign, visited friends in India in 1986, as he had done several times before. He was then beginning to focus on the coal mining and power generation project called Singrauli as the subject of the next Bank campaign. Singrauli was a disaster in both resettlement and environmental terms, he thought, but no NGOs, Indian or international, were calling attention to it; whereas by that time Narmada was already getting attention. He thought his and EDF's biggest value-added would be Singrauli. "It was virgin territory", he later said, making a bad pun. However, one day during his India visit he met, by accident, Medha Patkar, the leader of the NBA. She appealed to him to take up Narmada. Rich was doubtful: EDF was short of staff, a campaign was labor-intensive, difficult to do both Singrauli and Narmada, EDF could make more of a difference in Singrauli, etc. But he was
} 
international Narmada campaign shifted from gentle Oxfam in Britain to high-octane Udall in Washington DC. EDF began to use the Narmada case to make a broader attack on "development-as-practiced-by-the-World-Bank". On the ground, the NBA eclipsed ARCH and changed gears by early 1988. Instead of pushing for better resettlement it launched a "Stop the Dam" campaign. To many international NGOs Stop the Dam was more promising than Better Resettlement.

Patkar pressed Oxfam to declare whether it was for or against the dam, period. Oxfam refused to do so, and issued a statement saying why. It said that the dam would probably be built anyway, so oustees would need resettling; and that Oxfam was not qualified to judge whether and when large dams had a place in Indian development. Patkar pilloried the statement as "pro dam".37

Udall coordinated the international campaign in the period from 1988 to $1992 .{ }^{38}$ First, she identified groups within the more important Part I countries which might support a Narmada/Bank campaign and gave them a collective name, the Narmada Action Committee. (The "committee" was no more than the name Udall gave to her address file.) Second, she prepared menus of actions they might take in the circumstances of their own countries: parliamentary or congressional hearings, public forums, press conferences, lobbying key officials, letter-writing campaigns. She especially encouraged them to contact their legislators and their country's executive

impressed by her, and promised he would include it in a list of projects to take up with the World Bank and with Congress but without spending much time on it. Back in Washington DC he discussed the matter with new EDF recruit, Lori Udall. Medha Patkar, a great letter writer, began to deluge Rich with mail, which Rich, no letter writer, passed to Udall. Udall began corresponding with Patkar. Patkar visited Washington DC in September 1987 to attend fringe meetings around the Annual Meeting of the Bank and the Fund. People who heard her speak were impressed by her forceful personality, including Udall. She began to devoted most of her time to Narmada. Shortly afterwards she visited the valley, was aghast at the enormity of the human rights and environmental damage that was about to be committed, and energized by the dedication of the activists. She was able to learn a lot about the project from Oxfam and Survival International, both of which she was in close touch with.

Survival International had become involved in late 1984 through staff member Marcus Colchester (later of World Rainforest Movement). Colchester, who had detailed anthropological knowledge of the area, took up some specific angles that the other NGOs tended to neglect, to do with the cultural aspects of the life of the "tribals" (burial sites, places of worship, relationship with the communities they were to be moved into). Later, as the project moved into high crisis and relations between ARCH and NBA worsened, Colchester was the one "international NGO" person to maintain working relations with both Patel of ARCH and Patkar of NBA.

${ }^{37}$ EDF and Oxfam continued to cooperate on some matters. Together with Survival International they persuaded Bank President Conable to visit India in 1988 and meet with Narmada activists. The three NGOs sent a joint letter to NBA and ARCH leaders urging them to set aside their differences and present a common position to Conable - to no avail. Conable did meet with the activists - at World Bank headquarters in Delhi, the Indian government refusing to allow a venue "on Indian soil". The EDF/Oxfam split deepened in early 1992 when John Clark left Oxfam to join the World Bank.

${ }^{38}$ See her account of the campaign in "The World Bank and public accountability: has anything changed?", in Fox and Brown (eds.), The Struggle for Accountability, chapter 11. A valuable account, except that it air-brushes ARCH, Oxfam and John Clark out of the picture. 
director at the Bank. Third, she prepared information packs drawing on materials sent from NBA and other Indian activists. Throughout she was in frequent touch with the US executive director's office. The US Executive Director (ED), Patrick Coady, gave her full support.

Meanwhile, in a less visible way, the Bank Information Center (a Washington DC-based NGO which closely monitored the World Bank) and the Tuesday Group (a regular meeting of representatives of Washington DC-based development-oriented NGOs) kept track of the project. They pressed the Treasury to keep supporting the US ED and they maintained channels of communication between major NGO participants who refused to speak to each other directly (notably Udall, an active member of the Tuesday Group, and John Clark, not a member). And it was this group that especially saw the tactical importance of Narmada being a partly IDA-funded project (as Polonoroeste was not). The US Congress had more leverage over IDA spending than IBRD spending. By linking Narmada directly to the US IDA contribution they could more effectively get the Bank's attention. (IDA is the soft-loan arm of the World Bank, financed by grants from Part I governments-on which those governments can set conditions.)

The Bank's response to the gathering storm was to deny any significant problems, whether in Narmada or the Bank's environmental and resettlement work more generally. President Barber Conable personally replied to letters from some of the more distinguished letter writers. To all he said some variant of, "I appreciate your continuing concern, and can assure you that my commitment to environmental protection is shared by all of the senior managers in the World Bank. We are indeed proud of the achievements already in place, and I agree that we have done too little to publicize the good side of the Bank's efforts." ${ }^{39}$ He included a 14 page "Note on Narmada projects and World Bank involvement". The note concentrated almost exclusively on a description of Bank policy on environment and resettlement, without saying whether the policy had been implemented in Narmada; and it talked of actions that "will be" taken in Narmada. Neither the letter nor the document acknowledged real problems.

Bank staff were under strict instructions not to have contact with the NGOs, not even those on the ground in the valley. Thayer Scudder recalls an incident from 1985 when he and other members of a resettlement mission were staying in a resthouse. Word reached them that the leader of ARCH was coming to meet them. The mission leader ordered them all into hiding on the second floor, and the ARCH leader was informed that the mission was elsewhere and sent on his way. Scudder later made secret contact with $\mathrm{ARCH}$, involving a hair-raising midnight ride by motorcycle to a safe house in the back streets of a regional city, and ARCH supplied him with information which disproved the project authorities' assertion that insufficient private land was available for sale in Gujarat for oustees to be able to exercise any choice in the selection of their new land.

\footnotetext{
${ }^{39}$ Letter from Barber Conable to Randall Hayes (Rainforest Action Network) and Brent Blakwelder (Environmental Policy Institute), July 31, 1987.
} 
In 1989 the US-based NGOs in the campaign persuaded a congressional subcommittee to hold hearings specifically on Narmada. ${ }^{40}$ The hearings mark a watershed in international criticism of the Bank. Thereafter the international Narmada/ Bank campaign mushroomed. In response to the hearings six congressmen and women sent letters to President Conable calling for either a suspension or cancellation of the project, or otherwise face zero contribution from the United States to IDA. They said, "We believe that there is sufficient and compelling reasons [sic] that this loan should be canceled immediately". They continued, "As you know, the issue of replenishment for the International Development Association (IDA) will soon be before the Congress. We believe that this funding increase would be particularly difficult to justify to U.S. taxpayers unless the World Bank takes immediate steps to insure that all of the projects funded by IDA are in compliance with the stated policies of the Bank. Continued funding of the Sardar Sarovar project...raise [sic] questions about the Bank's ability to assure donor countries that minimal environmental, social and economic standards will be met in future IDA projects....we believe it would be a gross misuse of public funds to consider an increased replenishment for an institution which has demonstrated its disregard for human rights and environmental concerns". 41

For periods in 1989 and 1990 the president received as many as a thousand letters a day from the UK alone. In May 1990 the Japanese government announced it was freezing its aid for the dam's turbines and generators. This was in response to pressure from Japanese NGOs which had mobilized against Narmada, the first time they had taken a concerted position on international environmental/human rights issues. ${ }^{42}$ In June 199022 Japanese parliamentarians wrote to Barber Conable calling for the World Bank to suspend funding. ${ }^{43}$ US, European and Japanese media began to carry stories on the campaign. The New York Times first carried a story

\footnotetext{
${ }^{40}$ The subcommittee was the House Subcommittee on Natural Resources, Agricultural Research and Environment, chaired by James Scheuer. The same subcommittee chaired by the same Scheuer had earlier played an important role in getting the Bank to suspend disbursements in the Polonoroeste project.

${ }^{41}$ Letter from Congressman James Scheuer et al., to Barber Conable, November 2, 1989, emphasis added.

${ }^{42}$ The chair of the congressional subcommittee, James Scheuer, was also convenor of GLOBE (Global Legislators for a Balanced Environment). GLOBE held a meeting in Washington DC soon after the Narmada hearings. The meeting provided an opportunity for NGOs to discuss the problems of Narmada and the World Bank with the legislators. Japanese legislators were especially active in GLOBE, and took a particular interest in Narmada because Japan was the biggest co-financier of Sardar Sarovar. The GLOBE meeting triggered much greater involvement by Japanese NGOs in the Narmada campaign. Friends of the Earth (Japan) and other Japanese NGOs hosted the first International Narmada Symposium in April 1990, which brought together some 500 activists, journalists and academics from many nations. The head of Friends of the Earth (Japan), Yukio Tanaka, demonstrated a determination to get the Japanese government to withdraw from Sardar Sarovar that left even Lori Udall in awe.

${ }^{43}$ Open letter to Barber Conable, President, World Bank, from "Members of the Japanese Diet", June 26, 1990.
} 
about Narmada in 1989, in which it drew attention to NGO criticism of the Indian government and only obliquely mentioned the World Bank's role of what it called "limited support". ${ }^{44}$ By 1992 The New York Times carried seven articles about Narmada, with increasingly direct criticism of the World Bank. It quoted a prominent Indian environmentalist saying, "The World Bank is one of the most unaccountable institutions on the planet. It doesn't consult local people. Unless local communities really come into their own and are given control, you are not going to be able to save land and recover our ecosystem." ${ }^{45}$

At the time of the Annual Meeting in September 1992 some 250 organizations from 37 countries signed a full-page open letter in The Financial Times, The New York Times, and The Washington Post, which said, "The World Bank must withdraw from Sardar Sarovar immediately". The open letter went on to warn that if the Bank continued funding the project in the face of the Independent Review (which had presented its report in June 1992) then "NGOs and activists would put their weight behind a campaign to cut off funding to the Bank". ${ }^{46}$

\section{Internal Organization}

Inside the Bank, project management was from the beginning centralized in Washington, as was true for just about all Bank project work. The Bank's Delhi office had no-one responsible for the project until 1986. The first project officer was an economist with training in engineering, a young Young Professional with little prior experience. A new project officer took over in 1984, an experienced irrigation engineer already working on the project (described by friends as "a dams man"). In 1986 he moved to the Delhi office. But even then all correspondence between him and Government of India had to be signed off by the chief of the India Agriculture Division back in Washington, until 1989. The project officer found himself wrestling more than full-time with problems of procurement, design and construction. He and others in the project team devoted intense efforts to bring the dam up to international standards. They also struggled to persuade the Indian engineers to adopt more modern techniques of canal lining, fearing that the existing techniques would yield a lining unable to withstand the force of the water. Looking back from the mid 1990s, they see that great improvements were made on the infrastructure side, which makes them all the more bitter that the Bank eventually walked away from the project.

\footnotetext{
${ }^{44}$ Barbara Crossette, "Water, water everywhere? Many now say 'no!”, New York Times, October 7, 1989, sec.1, page 4.

${ }^{45}$ Smithu Kothari, quoted in Barbara Crossette, "What some preach in Rio is not what they practice at home", The New York Times, June 15, 1992, sec.A, p.8. I thank Anne Fentress for this reference.

${ }^{46}$ For example, The Financial Times, September 21, 1992, p. 6.
} 
Preoccupied with engineering problems the core people had little time for other things, and in any case they thought that problems like resettlement and environmental protection were minor compared to the benefits of getting the system up and running. They had no intention of pressuring the state governments to comply with the Bank's resettlement policy any more than they had to, believing the policy to be mistaken.

Their definition of priorities prevailed all the more because for much of the second half of the 1980s they were scarcely managed. Just as serious implementation began on the ground, when the project should have been intensively supervised, the Bank descended into the chaos of the 1987 reorganization. For more than 2 years many Bank staff were chiefly concerned to protect their own necks. Partly for this reason the India Agriculture Division-the division with shared responsibility for the Bank's most sensitive project by far and for the biggest agriculture/irrigation lending program in the Bank-had six division chiefs between 1984 and 1993, averaging about 18 months each. In the critical period from 1987 to 1989 three came and went in 18 months. The parent department had four directors between 1984 and 1990. The high turnover meant that during the 6 years that the project was the spearhead of a great campaign against the whole Bank the same two people were agriculture division chief and departmental director often for less than 12 months. This matters because incoming division chiefs and directors each took time to find out about the project (just one of many things they had to attend to). They encountered it as well established and took it as the project staff presented it. Across the Bank at this time there were many slips in projects because task managers, division chiefs and departmental directors were not paying attention.

Not until 1988 did the Bank institute any form of "crisis management", and even then the response was minimal. In that year, with the Narmada/Bank campaign rising, one person in the India Agriculture Division, Thomas Blinkhorn, was asked to take charge of all resettlement and environmental issues in Bank work in India, working directly to the director of the India Department. Blinkhorn came from a public relations background, with no experience in resettlement or environment, and his appointment illustrates how the India Department saw the problem as primarily public relations. ${ }^{47}$ Right up to project cancellation in 1993, Blinkhorn was the only person coordinating the Narmada resettlement and environment work; but he did this as just one item in a bigger portfolio of tasks that included several other resettlement

\footnotetext{
${ }^{47}$ Thomas Blinkhorn was an American public relations specialist who in the early 1970s had worked as a consultant to McNamara on how to make the Bank more sympathetic to poverty initiatives. Then he joined as a staff member working on Africa, followed by a spell in Information and Public Affairs, in which capacity he helped the Bank handle the criticism over Polonoroeste. He came to the India Agricultural Operations Division in 1986, began to consolidate the position of resettlement and environment czar for the whole department, and moved to the front office of the director of the India Department in 1990, until 1993. There has been much speculation about why he remained resettlement and environment czar for as long as five years, given all the controversy that swirled around him both inside the Bank and in India and given the need for someone with a more delicate public relations touch than his.
} 
and environment hot spots in India. He had no assistant. For several years his normal working day was $12 \mathrm{~h}$.

Blinkhorn believed that Sardar Sarovar and the proposed upstream dam, Narmada Sagar, were good investments that were in danger of being blown away by ill-informed critics. He shared the project staff's skepticism of the motives and competence of the Bank's own resettlement and environmental staff, who were, said the project officer, "in a unique position of being able to communicate the non-optional, critical life-supporting need for development of the Narmada's water and power resources but....chose to work tirelessly to criticize the SSP [Sardar Sarovar Project] planning and implementation processes, and thereby contribute to delays while remaining ever mindful of setting up detailed criteria requiring bureaucratic manipulation-empire building-for which they were well suited." 48

In the eyes of the Bank's resettlement and environment staff, Blinkhorn began to act as a gatekeeper confining them to the sidelines and doctoring their reports. When they wrote about bad conditions in resettlement villages he assured his superiors that he had visited the same villages and found conditions much better than they said. He complained to their own departmental directors about their "uncooperative" attitude. They in turn found his abrasiveness intolerable. "There was no problem small enough for Blinkhorn not to turn into a major one", said one. Another said, "Any news that might justify not going ahead was strongly unwelcome in the project line. Staff and managers would say, 'This afterall is India. We can't expect to solve problems except by muddling through.'" Their deprecation of India was untroubled by comparison with the Bank's own chaos of 1987-88 as it underwent the Conable reorganization.

Relations between the project people and the environmental and resettlement people got worse and worse. Since the two sides were not in the same division or department antagonisms could flourish as each dug in. By 1990 everyone was at each other's throats. The India Department blamed the Asia Regional Environment Division, the environment people blamed the project people, Bank staff blamed the Indians, the Indians blamed the Bank, the central government blamed the states, the states blamed the central government, the NGOs blamed everyone. ${ }^{49}$ Relations between the project people and the NGOs were even worse, with the Bank attributing to them the worst possible motives. The project officer referred to "the extreme intellectual dishonesty and related pressure tactics of the NGOs". They were practicing, he said, "tactics well honed in western USA in the 60s and 70s". Their concerns about resettlement and environment were mere "tools of delay needed to

\footnotetext{
${ }^{48}$ Personal communication, Gerry Fauss, 14 January, 1996.

${ }^{49}$ In 1992 the Environment Secretary, Government of India, refused to meet with Thomas Blinkhorn, the India Department's environment and resettlement czar. Blinkhorn made an urgent request for a meeting, wanting to persuade the Secretary to undertake a National Environmental Action Plan, such a plan being required of all IDA-eligible countries as a condition of further IDA funding. It took a request from the South Asia vice president to the Finance Secretary to persuade the Environment Secretary to change his mind. He looked thunderous and drummed his fingers on the table throughout the meeting.
} 
organize the world net of anti-large-dam believers into a formidable political block". 50 The Bank must not cave in to such dishonest people, the project staff said.

On the other hand covert relations between the resettlement and environment people and the NGOs were good. The project people, Blinkhorn above all, never realized that their efforts to block the views of the resettlement and environment people from senior management forced them to go outside the Bank to the NGOs once it became clear that the NGOs had better access to senior management than they did.

\section{India's Crisis}

Just as the Bank began to pick itself up after the 1987-88 reorganization India hit a severe macroeconomic and political crisis. By 1991 the crisis was so bad that "A default on [international debt] payments, for the first time in our history became a serious possibility in June, 1991", in the words of a government report. ${ }^{51}$ In response the government committed itself to a far-reaching program of economic opening, hoping to restore the capacity to generate foreign exchange in a sustainable way. "Bankruptcy drove the reform process, not ideology", said one analyst. ${ }^{52}$ The central government was keen to involve the Bank in finding a way out of crisis, promising in return drastic economic liberalization. This was the golden opportunity the Bank had been waiting for. For several years the macroeconomic and political crisis and then the opportunity for far-reaching liberalization crowded out senior managerial attention to other things, like Narmada, both in the Indian government and in the Bank.

At the same time, the crisis stiffened the senior management's resolve to keep Narmada going ahead, to avoid a showdown, precisely because so much was at stake in the liberalization agenda. A senior manager said, "At senior levels there was an overarching concern that relations with India were delicate, and that the consequences of failure in Narmada were so great that the entire India portfolio might be in jeopardy".

And so the core project people, led by the director of the India Country Department, ${ }^{53}$ backed up Thomas Blinkhorn, and strongly supported behind the scenes by Ernest Stern, godfather of the special Bank-India relationship, acted as though marching to the German Army slogan, "Augen zu und durch!", Eyes closed and through!

\footnotetext{
${ }^{50}$ Gerry Fauss, op.cit., emphasis added.

${ }^{51}$ Government of India, Ministry of Finance, Economic Survey 1991-1992, Part I: General Review, New Delhi: Ministry of Finance, 1992, p.10.

${ }^{52}$ Swaminathan Aiyar, The Economic Times, 15 August 1997:5.

${ }^{53}$ Heinz Vergin.
} 


\section{The Independent Review}

The Executive Directors found themselves thoroughly confused. The staff told them the project was OK. The NGOs said the Bank remained far out of compliance. In 1988 the Dutch executive director, Paul Arlman, began to take a particular interest in Narmada and convened a group of Part I country EDs to follow it. ${ }^{54}$ They had to rely on what the India Department staff told them orally or in sanitized briefs; they had no access to back-to-office reports. ${ }^{55}$ Some of them met with Oxfam's John Clark, EDF's Lori Udall, and the NBA's Medha Patkar. After the meeting with Patkar one ED commented, "When I hear what NGOs say about this project and then what the operations people say, it sounds like they are talking about two different projects". 56

The group of concerned EDs was briefed by Scudder in 1990, arranged by Lori Udall. By that time Scudder had been back from his 1989 mission for a year-the

\footnotetext{
${ }^{54}$ The Indian executive director, though invited, did not attend these meetings until 1990. In addition to Holland, the participating EDs represented the UK, the US, the Nordic countries, Canada, Japan, Germany, Australia, Belgium and later Switzerland.

${ }^{55}$ One such meeting was held in March 1990. It was attended by the EDs from Holland, the US, and the UK, and by Senior Vice-president for Operations Qureshi and four other Bank staff. The Dutch ED opened the meeting by stating that "while he had confidence in the Bank managers and staff working on the projects and was aware that a certain amount of progress was being made in project implementation, he was nonetheless very concerned about other developments....these other developments included 'major interests' in the Part I countries, and increasingly in the Part II countries (including India), as well as active non-governmental organizations which either oppose or are very critical of the project. Eventually, these interests could draw the Bank into a situation in which the outcome would be unsatisfactory to the project and detrimental to the Bank as an institution." "The senior vice-president for operations responded by asking what might be done to lead to a more satisfactory conclusion. [He said he was in close contact with the project, and felt optimistic about project progress.] In the circumstances, he continued, it would be wrong for the Bank simply to abandon the project in its current inconclusive state. Our continued involvement and influence can help to ensure that those aspects that concern critics the most-resettlement and environment - will receive priority attention and careful and proper implementation.... The essential point, he continued, is that the Bank sets specific standards for project performance. It is then up to the governments to implement the project in accordance with these standards. If they don't, it is then relatively easy for the Bank to suspend or withdraw. However, if Governments are meeting the standards, making best efforts to implement projects satisfactorily, we have an obligation to work with them to see the project through to a satisfactory conclusion." (Thomas Blinkhorn to Distribution, March 14, 1990.)

Note the senior vice-president's sentence, "If they don't [implement the project in accordance with Bank standards], it is then relatively easy for the Bank to suspend or withdraw." In its public or semi-public defence, the Bank frequently draws attention to the sanction of suspension or withdrawal and its willingness to use it if circumstances warrant. The key, of course, is what circumstances warrant. As everyone in the room knew, the Bank has hardly ever suspended or withdrawn from a project on environmental or social grounds anywhere, and by 1990, the year of the meeting, had never once suspended or withdrawn from an Indian project. It was not "relatively easy" for the Bank to suspend or withdraw. Qureshi's statement was intended to reassure the EDs that the Bank was fully in control.

${ }^{56}$ Quoted in Lori Udall, "The international Narmada campaign: a case study of sustained advocacy", in William Fischer ed., Towards Sustainable Development? Struggling Over India's Narmada River, Armonk: M.E.Sharpe, 1995, p.206.
} 
mission on which he had urged suspension on grounds that nothing short of suspension would force improvement in resettlement. His meeting with the EDs lasted three hours. The EDs were shocked by what he said, so different was it from the staff's story. Scudder asked the Board to order the Bank to stop disbursements. $\mathrm{He}$ argued that the Bank had never taken a tough stance on resettlement in any Indian project, and that doing so would send a signal not only to India but also to other countries with poor resettlement, like Brazil.

In 1990 Oxfam wrote a report on resettlement and environment in Narmada. The report said that there was good news and bad news: some progress in Gujarat, little progress in the other two states. The India Department (Blinkhorn) quoted the Oxfam report in its report to the EDs-but only the good side. Oxfam then sent a blistering letter to the full Board, giving the full text and highlighting how the department had sought to mislead the recipients. This was a triggering event in many EDs' conviction that Bank management simply could not be trusted.

In mid 1990 the US ED began to sound out the Director-General of the Bank's Operations Evaluation Department (OED) about undertaking a special review of Sardar Sarovar. The idea was greeted with unease all around, because it would take the OED too far from its mandate of reviewing completed projects.

Then at the end of 1990 Medha Patkar and the NBA led a "Long March" in which thousands of people from the valley set out to walk to the dam site where they planned to stop construction by means of a sit-in. They were stopped at the Gujarat border by police. Medha Patkar and several others began a fast-to-the-death. The fast injected new urgency. What would persuade Patkar to stop? She was demanding that the whole project be comprehensively reviewed, but the Bank would not agree. As she grew weaker and the Bank said nothing John Clark, Lori Udall and others made desperate attempts to convince the senior operational vice president, Moeen Qureshi, to announce a review. Finally, Clark in Oxford, England, spent an entire night on the telephone mediating between Qureshi five hours behind in Washington and Oxfam and other NGO activists five hours ahead in India. By the end of Clark's night, Qureshi agreed to establish an independent review of Narmada. Patkar called off her fast.

In the spring of 1991 a small number of EDs led by the new Dutch ED, Evelyn Herfkins, began to consider the membership and terms of reference of an independent review panel. There were no precedents to draw on. Herfkins used her by then well-established contacts with NGO people like Udall and Clark to get ideas. But since the independent review would be established by the Bank, the India Department's resettlement and environment czar, Blinkhorn, was made responsible for establishing it. He approached a number of prominent persons to invite them to head it. All refused. Meanwhile Conable, in the waning months of his presidency, was getting desperate; he needed someone fast. With support from Herfkins and the other interested EDs, he approached his former congressional colleague, Bradford Morse, who since leaving the US Congress had been head of the United Nations Development Program (UNDP). Morse was in poor health. But Conable prevailed on him to chair the commission while others did the work. 
In June 1991 Conable announced that an independent review panel would be established, headed by Morse. Blinkhorn started to look for someone to head up the real work. By this time the Environmental Defense Fund's Lori Udall was, as he said, "practically camping in the living room", getting so many leaks out of the Bank that she was better informed than he was. ${ }^{57}$ Udall started a letter writing campaign aimed at the Dutch ED Herfkins to persuade her to push for the appointment of Thomas Berger as the principal investigator. Berger was a well-known Canadian jurist and advocate of native American rights. He was also a friend of Udall's uncle, former US Secretary of the Interior Stuart Udall, who had subsequently worked closely with Berger in a major legal case on native American rights. Barbara Bramble, one of the trio that led the earlier NGO-Polonoroeste campaign against the Bank and now working behind the scenes on this one, had also worked with, admired, and advocated Berger. Herfkins proposed Berger. Blinkhorn interviewed Berger and recommended him, even knowing his reputation as a defender of indigenous people's rights and knowing that there were many tribals in the Narmada area, in order to show that the Bank was bending over backwards to be impartial. Morse agreed. Berger named conditions. He would receive a fee of \$1500/day (an unheard of rate in the Bank for a long-term assignment, to which the head of consultants' services in the Human Resources department made the strongest possible objection), and he would pick his own team (whom he named). By this time it was August 1991. Conable and Senior Vice President Sandstrom were anxious to end the already long delay. They accepted Berger's conditions. He was appointed deputy chairman of the investigation panel.

The NGO community was delighted. Many in the Bank were dismayed. They observed that the panel members had little knowledge of development (Morse apart) and no knowledge of India. They saw the fact that the chairman had been head of UNDP as ominous. "Of course, anyone related to UNDP [Mr Morse] would not miss an opportunity to embarrass the Bank", said one. ${ }^{58}$ Conable himself warned Morse that Berger and his team might, on the basis of their track-record in handling native American issues, pre-judge the issue. Morse reminded Conable that he had obtained a pledge of absolute independence. Conable backed off.

Once the core members of the Review were appointed they had frequent contact by phone with Udall, and on their first visit to the Bank met with her at their hotel for three hours. It was true, as their critics alleged, that they knew little about the Bank and less about India. She briefed them on such issues as how they could retain their credibility in the NGO world, which NGOs were fighting which, which were trustworthy, who was doing what in the Bank, and what rules of operation to insist upon vis-a-vis the Bank. Berger also spent a day with Clark and others at Oxfam. The team formally started work in September 1991.

\footnotetext{
${ }^{57}$ Thomas Blinkhorn, interview, April 3, 1996.

${ }^{58}$ Senior legal official to a subordinate, comment in the margin of a copy of the Terms of Reference of the Independent Review.
} 
Its independence from the Bank was ensured by several rules that the review panel (after the briefings from Udall and Clark) had insisted upon:

1. Complete access to all project files from the Bank and from Government of India, and to Indian NGOs and the Narmada valley.

2. An extended period of time (originally 7 months, increased to nine).

3. An independent budget, initially of $\$ 400,000$ that grew to about $\$ 1$ million. (The budget came from the President's contingency fund.)

4. Independent publication of the results, without Bank editing.

5. No post-Review Bank employment of panel members.

Its terms of reference were limited to resettlement and environment, its task being to assess the Bank's performance in these two domains in relation to the Bank's own policies and loan agreements. The NBA initially opposed such narrow terms of reference on the grounds that many other aspects of the project had also been questioned. The Bank stood firm, and there was an indication that the Indian government had agreed to the review on condition that it be confined to resettlement and environment. ${ }^{59}$ All the Indian state governments were angry that the Bank had created such a body. Gujarat, in particular, wanted nothing to do with it. The Bank had to use maximum leverage with the Chief Minister of Gujarat to obtain permission for the panel even to visit the state.

Ten months later, on June 18th 1992, the panel issued a 363 page report. The report concluded, first, that the Bank had been seriously out of compliance with its own directives on both resettlement and environmental analysis of projects; second, that "there is good reason to believe that the project will not perform as planned"perform in the hydrological sense of getting the water to the expected areas; third, that adequate resettlement was unlikely to occur on the ground "under prevailing circumstances", because "a further application of the same [incremental] strategy, albeit in a more determined or aggressive fashion, would fail". Finally, it recommended that the Bank "step back" from the project. Essentially, it confirmed most of what the NGO campaign had been saying.

The Review also found that "the richest source of material about the problems with resettlement in India are in the Bank's own internal documents", making it all the more "perplexing [that] there seemed to be so little effort to develop a remedial strategy rather than confront one resettlement problem after another" 60 One Review member commented that if key people in the India department had listened to their own mission members and consultants the whole review exercise would have been unnecessary. ${ }^{61}$

The panel presented the Review to the Board shortly before its public release. The Board pressed Berger to explain what he meant by saying that the Bank should "step back" from the project. Suspend or cancel? Berger's reply sounded evasive, leading

\footnotetext{
${ }^{59}$ Udall, "The international Narmada campaign".

${ }^{60}$ Independent Review, op.cit., p. 53, emphasis added.

${ }^{61}$ Quoted in Udall, 1995, “The international Narmada campaign”, op.cit., p.210.
} 
to speculation that Conable made a deal with Morse that the Review could recommend anything other than outright cancellation (which Conable denies). ${ }^{62}$

The report caused outrage in the India Department. It showed that members of the review panel were completely unqualified for the job, knew nothing about development or India, approached their task with preconceived conclusions, were captives of the NGOs, and as outsiders to the Bank had fallen into the trap of interpreting its policy guidelines literally. The panel had interviewed none of the core project team, India Department members said indignantly.

On the legal side, the General Counsel and Legal vice president, asked by the EDs for an opinion on whether the Bank had legal grounds for suspension or cancellation, wrote a memorandum that did not clearly say one thing or the other. ${ }^{63}$ But the chief legal counsel for the South Asia region wrote another memorandum setting out ample justification for suspension or cancellation. ${ }^{64}$ When the General Counsel squashed this memo, it mysteriously leaked to NGOs, which circulated it to finance ministers and EDs. It became part of the grounds on which several EDs were later to support cancellation. Meanwhile other South Asia Legal Department staff pronounced themselves "shocked" by the magnitude of non-compliance revealed by the Review. The India Department retorted that they were "shocked" as in "cover your arse". They knew perfectly well the nudging and winking that had always gone on over India's non-compliance with Bank procedures, said the India Department.

Fortunately for the Bank, the report was released 4 days after the United Nations Conference on Environment and Development (the Rio Earth Summit) had designated the Bank as the key agency to implement "Agenda 21", an informal intergovernmental agreement on global environmental priorities and actions. ${ }^{65}$ So in the same week in 1992 the Bank emerged from the Rio Earth Summit as international environmental savior, and emerged from a 10-month review looking incapable of addressing environmental and resettlement impacts in its own projects. ${ }^{66}$

\footnotetext{
${ }^{62}$ Author's interview with Conable, 1 April 1996.

${ }^{63}$ Ibrahim Shihata, "Remedies available to the Bank/IDA under the loan/credit agreements on the Sardar Sarovar projects", July 16, 1992.

${ }^{64}$ Ian Newport, Chief Counsel, LEGSA, to William Humphrey, Acting Director, SA2DR, August 7, 1992.

${ }^{65}$ Was it planned or fortuitous that the report was released just after the Bank had been identified as the lead agency for Agenda 21? I do not know.

${ }^{66}$ Udall, "The international Narmada campaign", p.201. For two contrasting assessments of the report see Thomas Berger, "The Independent Review of the Sardar Sarovar Projects 1991-1992", Impact Assessment 12 (Spring), 1994, pp. 3-20; and David Seckler, "The Sardar Sarovar project in India: a commentary on the Report of the Independent Review", Discussion Paper 8, Center for Economic Policy Studies, Winrock International Institute for Agricultural Development, Washington DC, 1992.
} 


\section{The Decision to Continue, and then to Cancel}

In July 1992 the Bank sent a large (14 person) mission ${ }^{67}$ to review the status of the Sardar Sarovar project. The mission leader was anxious to have a member of the Department of Economic Affairs (the department within the Ministry of Finance that handled GOI/Bank and Fund relations) accompany it on its visits to help mediate relations with the states. The state governments were deeply hostile to the Bank, believing it was trying to foist on them resettlement policies written in the land of make-believe. The state governments were also resentful of Delhi for doing so little to moderate the Bank's demands.

The India Department's environment and resettlement coordinator, Blinkhorn, arrived a week before the rest of the mission to prepare the way. He asked the Department of Economic Affairs to delegate someone to accompany the mission. The department refused; it wished the Review and the Bank's response to be strictly a Bank affair. The evening before the mission left Delhi to fly to Gujarat Blinkhorn telephoned a middle ranking official of the division of the department that handled Bank agricultural/irrigation projects (including Sardar Sarovar) to say that he had instructions from the Finance Secretary that she was to accompany the mission to Gujarat. She was alarmed, for she was new to the division and knew nothing about Sardar Sarovar, yet Gujarat officials would turn to her for Government of India's views. She tried to contact the Finance Secretary, but he was out of town. She decided to trust her instinct and stick with the decision that had already been made by the department: she refused to go. Later she learned that the Finance Secretary had not even spoken to Blinkhorn, let alone issued such an instruction. The incident became known in the top management of the Department of Economic Affairs, and further inflamed the department's mistrust of the Bank.

The mission was received with hostility wherever it went. Tensions in the valley were running high as rising numbers of protesters encountered rising numbers of police. ${ }^{68}$ At one point human rights observers reported seeing mission members traveling through the villages of MP with an escort of 200 police. $^{69}$

The mission leader concluded that the Bank should suspend disbursements, and recommended this in the Back-to-Office report. Instead of saying, "You have six more months to do things $\mathrm{x}, \mathrm{y}, \mathrm{z}$ " the Bank should say, "We'll suspend now and resume when you have done $\mathrm{x}, \mathrm{y}$, and $\mathrm{z}$ ". None of the mission members, including those resettlement experts who had not hesitated to criticize the Bank's performance, wanted cancellation, because they were convinced that without the Bank being involved resettlement and environmental protection would be worse.

\footnotetext{
${ }^{67}$ Known as the Cox mission, after its leader, Pamela Cox, a member of the India Department who had not previously worked on Narmada. The other mission members also had no "ownership" of the project.

${ }^{68}$ Patti Grossman, "Before the deluge: human rights abuses at India's Narmada dam", Asia Watch, June 17, 1992.

${ }^{69}$ Udall, "The international Narmada campaign", p.217.
} 
Suspension and cancellation are the Bank's heavy artillery, and their use is strictly in the hands of the senior management. Managing Director Stern ${ }^{70}$ decided that the Bank would neither suspend nor cancel but continue for another 6 months, or more precisely, that the Bank would recommend this to the Board, for the Board had already, very unusually, asked to reconsider the Bank's involvement in the project. Stern and the senior management's argument to the Board was, "After a rocky start we have finally got a good partner in the Government of Gujarat, the Bank is demonstrably helping to improve the project, the project is potentially a very good one, of great importance to India as a whole, why cut off the branch we are sitting on, why abandon it in mid stream, what good would it do to anyone (most of all the oustees) to stop now?" And they repeated, "We mustn't cave in". The senior managers also had in mind the signal that suspension would send to international finance markets, at a time when India's recovery from the macroeconomic crisis was not yet sure.

For the September 1992 Annual Meeting the international NGOs ran the full-page advertisements in the three newspapers most widely read among the Annual Meeting delegates, warning that if the Bank continued funding Sardar Sarovar against the advice of the Independent Review then "NGOs and activists would put their weight behind a campaign to cut off funding to the Bank". The vice president for South Asia and other senior managers lobbied delegates to put pressure on their governments in favor of continuing the project. Several from countries whose executive directors later voted in favor of suspension told these officials, "We see the sense in your arguments, but we are obliged by the political situation to be critical of the Bank in public".

Also in September 1992 the Bank presented to the Board a document called "Sardar Sarovar Projects, Review of Current Status and Next Steps". 71 This interwove the Bank's reply to the Independent Review's Report with its own "action plan" for dealing with resettlement and the environment. It was to have been the work of a task force set up to reply to the Independent Review's report, with membership drawn from both the India department and the environment and resettlement complex, the first time in the project's history that such a task force had been attempted. The result was failure. The task force was paralyzed by disagreement, and in the end Blinkhorn wrote it himself to a murderous deadline, working directly to the vice president and to Managing Director Stern, consulting hardly anyone else.

The "Next Steps" document satisfied virtually nobody. Operational people in the India Department resented the fact that the people working on the project were not allowed to reply to the Review's report themselves, as a consequence of which the "Next Steps" reply was not as convincing a rebuttal as it should have been, they said. The lawyer for the project was also unhappy, saying that the action plan "is neither precise nor monitorable". He went on to say, "We seem to be moving away from a

\footnotetext{
${ }^{70}$ In the mini-reorganization of late 1991 Stern became one of three managing directors.

${ }^{71}$ Dated September 11, 1992.
} 
situation where compliance or non-compliance of GOI [Government of India] and the states are measured against the legal documents, to a situation where it is unclear exactly what is being agreed upon and what commitments are being made by GOI and the states under the action plan". ${ }^{72}$ Indeed, "Next Steps" was intended to be ambiguous, so as to allow maximum scope for a political determination of what should be done.

Other internal critics observed that "Next Steps" flew in the face of the Bank's ostensible objective of getting India to take more ownership of the project: the action plan had been drawn up by the Bank with no input from the government.

The review panel members were even more unhappy with "Next Steps". They claimed that the Bank had seriously distorted their findings - though their report was in the public domain for all to see. In October the chairman and deputy chairman of the Review, Bradford Morse and Thomas Berger, wrote to the president saying that the Bank's reply “ignores or misrepresents the main findings of our Review....[W]e do want to ensure that the senior decision-makers at the Bank are not left with an account of our findings that is at variance with what we wrote." 73 They went on to say that the Bank's presentation of its findings gave the impression that their report found the problems with the project to be much smaller, more tractable, than the report actually suggests. Panel members subsequently flew to Washington to meet with the Board.

The vice president for South Asia signed a two and a half page response to the Morse and Berger letter (copied to the Board), rejecting virtually all its claims. ${ }^{74}$

The Board met to vote on the fate of the project on October 23, 1992, a few days after South Asia's response to the Morse/Berger letter. The president, the South Asia vice president and other high-ranking Bank officials were in attendance. (This was

\footnotetext{
${ }^{72}$ Salman Salman, LEGSA, to Andres Rigo, Assistant General Council, Operations, September 15, 1992.

${ }^{73}$ Bradford Morse and Thomas Berger, to Lewis Preston, October 13, 1992, emphasis added. Here is an example of what Morse and Berger claimed to be Bank distortion of the Review's message. The Review documented the project's disregarding the environmental clearance procedures of both the Bank and Government of India. It stressed that an environmental workplan setting out a strategy for dealing with environmental problems was still not available in 1992, though legally required by the Bank by end 1985 and by India's conditional environmental clearance by 1987 . The Bank answered that "there have been no severe environmental consequences to date because of study delays", and that an environmental workplan was "under consideration". Morse and Berger replied to the president, "Of course there has so far been. . . 'no severe environmental consequences'. The ... dam has yet to impound any water and the canal is not yet functional". The Bank's operational directives recognize, said Morse and Berger, that environmental planning must be done before or in the early stages of construction so that the design and implementation of construction can take account of the results. The Review, they said, had strongly criticized the Bank for accepting the pari passu principle of doing environmental studies on a timetable that ensures the studies are completed by the time the construction is completed. This is simply too late, they said. The Bank's summary of the Review had missed this fundamental point. As for an environmental workplan being under consideration, "This kind of 'consideration' has been underway in one way or another to no avail for the last six years", they retorted.

${ }^{74}$ Joseph Wood to Bradford Morse, October 20, 1992.
} 
the third time the Board had met for an all-day meeting on the project since the Morse Commission began.) The South Asia vice presidency had prepared a series of "benchmarks" of what should be achieved on the ground over the following 6 months, to strengthen the case for extending the Bank's involvement by at least another 6 months. These benchmarks tied the rate of construction of the dam and canal to the rate of (improved) resettlement. Failure to meet the benchmarks would provide grounds for the Bank to pull out.

Bank staff present at the meeting remember it for the sheer vindictiveness of the executive directors. The Dutch ED, who had taken a coordinating role for the project within the Board and between the Board and the Bank, reminded the meeting that the Board had asked for an independent review because it felt it could not trust Bank management. The Austrian ED criticized Bank management for its strong-arm lobbying of the EDs to keep the project going. The US ED, Patrick Coady, accused management of a "coverup", noting that "what is at stake is the credibility of the Board". He went on to say that if the Board allowed the project to continue "it will signal that no matter how egregious the situation, no matter how flawed the project, no matter how many policies have been violated, and no matter how clear the remedies prescribed, the Bank will go forward on its own terms". 75

The Bank's management gave as its core argument one that had by then become its standard justification for involvement in all difficult projects. Using almost identical language to Polonoroeste it said, "While it would be safe to restrict Bank involvement to those situations in which the Borrower had already established an exemplary track record, this would in practice mean foregoing opportunities for potentially more important change. A decision by the Bank not to get involved could well mean that the project in question will still proceed but under much less favorable circumstances" ${ }^{76}$ It did not say, though this was in its mind, that cancellation would damage the Bank's reputation as an infrastructure lender in India and the rest of the world.

Much of the discussion concerned the benchmarks against which progress would be monitored. Some EDs raised the worry, already voiced by many NGO critics, that the benchmarks depended on the governments of MP and Maharashtra doing things they were disinclined to do, while the Government of India patently had little influence over them. Therefore, said the critics, the benchmark exercise was dishonest because based on an assumption that everyone knew to be false: that Government of India, which had agreed to implement the benchmarks, had influence over MP and Maharashtra and therefore that its sign-on meant something on the ground.

At the Board meeting the UK ED asked the key question: had the "relevant authorities" agreed to the benchmarks (meaning in particular had the state governments agreed)? The Indian ED gave an answer that left everyone unclear whether he meant yes or no or maybe. Managing Director Stern, in the chair, replied to the UK

\footnotetext{
${ }^{75}$ Quoted in Rich, Mortgaging, p.301.

${ }^{76}$ The quotation comes from the first draft of the Bank management's response to the Independent Review, dated June 23, 1992, p.12.
} 
ED: "The answer is yes". The UK therefore cast its vote in favor of continuing. Until that moment the outcome of the vote had been in doubt. The US, Germany, Japan, Canada, Australia, and the Nordic countries had indicated their intention to vote for suspension. But they accounted for a minority (42\%) of the vote. The UK's vote for continuing tipped the balance. The majority-including all the Part II countries"wished to give the benefit of the doubt to the new Government of India and to acknowledge the recent efforts made by the Indian authorities"77. They therefore urged that the Bank should continue to disburse subject to a review against benchmarks 6 months on.

The fact that the Bank acted against the advice of the Independent Reviewhelped by the ambiguity in the Review's recommendation to "step back"-reenergized the international opposition to the project and to the Bank at large. On the ground construction progressed while resettlement lagged far behind. On the other hand, environmental analysis suddenly took off. In the 6 months following the independent review more progress was made towards the formulation of a regional environmental work plan than in the previous 6 years. Both the director of the India Department and key people in India finally accepted that the issue could not be fudged. This is a milestone in the Bank's environmental history.

A senior Bank manager admitted in 1993 that suspension in 1989 would have been a healthy "shock" that might have speeded up action on the ground to fix resettlement and environmental problems. ${ }^{78}$ But the "shock" thesis was consistently rejected right up to 1993, in favor of the argument that incremental progress should be rewarded even if not sufficient to reach agreed deadlines.

At the end of March, 1993, the Board was scheduled to decide whether to continue. By then it was clear that the benchmarks set 6 months before, especially those to do with resettlement, would again not be met on the ground. South Asia Vice President Joseph Wood, who had strongly resisted suspension or cancellation since taking charge in 1991, became persuaded there was no alternative. Government of India and Government of Gujarat had indicated they would not say, "We will stop building the dam until these other matters are in hand". On the contrary, their attitude seemed to be, "Damn the NGOs, we are not going to submit to crybabies, we will continue to build the dam". They did not wish to accommodate the Bank's attempts to respond to world outrage. In any case, it had become blindingly obvious that the lack of unified decision making between the federal government and the states, plus the difficulties of cooperation between the states, meant the Bank could not count on Indian assurances. This argued against mere suspension, leaving cancellation as the only choice.

And cancellation now looked to be necessary in order to protect IDA from the continuing storm. For some years the finance complex of the Bank (which raises

\footnotetext{
${ }^{77}$ Chairman's summary, “India: Sardar Sarovar projects", Executive Director's meeting, October 23, 1992.

${ }^{78}$ Quoted in Hans Wyss, "Bankwide lessons learned from the experience with the India Sardar Sarovar (Narmada) project", May 19, 1993, p.5.
} 
IDA money) had pressed the South Asia region to close down Narmada. A director in the financial complex asked Blinkhorn in 1991, "When are you guys going to close that project down? It is killing IDA". ${ }^{79}$ The Board's decision to continue disbursements, coupled with the Bank's alleged misrepresentations of the Independent Review, lead the Narmada campaign to focus its attention on cutting off the $\$ 18$ billion dollars for the tenth replenishment of IDA (IDA-10), then being negotiated. In the spring of 1993 Washington-based NGOs testified in Congress that they would oppose IDA funding unless the Bank (a) cancelled the loan, (b) undertook a complete revision of the Bank's information policy, and (c) created a citizen's appeals panel to give affected people direct access to an independent body to assess their complaints. This last is the embryonic idea of what became the Bank's Inspection Panel.

Representative Barney Frank, chair of the key IDA-authorizing subcommittee (the House Subcommittee on International Development, Finance, Trade and Monetary Policy) privately informed the senior management that he would refuse to authorize the US's $\$ 3.7$ billion share of the IDA replenishment until these conditions were met. He was in close touch with the NGO leaders.

By March 1993 a majority of the Board favored cancellation. In the end, President Preston informed Prime Minister Narasima Rao that Narmada was jeopardizing IDA, and India was a major beneficiary of IDA. ${ }^{80}$ The vice president for South Asia told the Indian government, "Either we cancel or you tell us you will not submit requests for disbursements". In the end the need to protect IDA outweighed worries about the Bank's loss of credibility as an infrastructure lender and the Bank's special relationship with India.

A few days before the Board meeting the Government of India announced that it would not ask the Bank for more disbursements. The central government was not unhappy to cancel. The project was generating too many headaches, and the benefits of Bank involvement went largely to Gujarat, not to the center. A senior Indian official said, "The project had become a cancerous tumor on the country's overall portfolio with the Bank". ${ }^{81}$ Needing Bank help in publicizing India's market reforms, the government wanted embarrassing distractions like Narmada removed from the spotlight. Indeed, taking the moral high ground, the government explained

\footnotetext{
${ }^{79}$ This was the common view in the financial complex, but of course it was not shared by Ernest Stern, the senior vice president for finance for several years prior to the beginning of 1992.

${ }^{80}$ This is the paraphrase by a close participant. Rumors persist of a deal between Preston and Rao for the Bank to boost IDA disbursements to India through other channels so that India suffered no foreign exchange loss. It is not possible to confirm the rumor from IDA disbursements figures because the amounts disbursed year by year have complex and lagged determinants. There is a wellestablished principle that India gets about 18 percent of the IDA total, which works out to $\$ 800$ to $\$ 1,000$ million a year. (China gets another 15 percent.) Through the period of cancellation total IDA commitments to India held fairly steady. The chief problem for IDA and India has been to find enough projects to absorb India's 18\%. At the end of FY1993 Stern was urging the India department, "You've got to get another $\$ 400$ million [in project commitments] to bring India up to 18 percent".

${ }^{81}$ Quoted in “A tactical retreat to save face?", Pioneer (India), March 31, 1993.
} 
that its decision reflected determination to upholding the quality of the planning and consultation processes even at the cost of not meeting the arbitrary deadlines agreed with the Bank 6 months before. ${ }^{82}$

In private Indian officials said that what the Bank had been doing was "not in keeping with the country's self-respect". 83 They claimed the Bank had been exercising inordinate influence given that it was contributing only $15-20 \%$ of the funds. And they recognized that the gap between Bank resettlement requirements and what India was able to deliver would almost certainly persist and be the source of constant future problems. Finally, the cost of cancellation was by this time not very high. The IDA (almost zero interest) component had already been disbursed, leaving the (almost commercial rate) IBRD funds to be canceled.

The leader of the main opposition movement, Medha Patkar, sent a message from a remote Narmada village saying the loss of World Bank funds was "a victory for thousands of struggling tribals and farmers in the Narmada valley". ${ }^{84}$ The NBA then succeeded in getting the Supreme Court to halt dam construction in early 1995, until resettlement was carried out in line with India's and the Bank's policies.

\section{Why Narmada?}

Narmada became the second spearhead of NGO mobilization against the Bank, the second trampoline, not because it was bad compared to other Bank projects or because mistakes were made that were not made elsewhere. On the contrary. Like Polonoroeste, Sardar Sarovar was prepared by people who were idealists and innovators, who believed they were helping to make fundamental improvements in borrower governments' practice.

It became the second focus of attack because it had several characteristics that helped the organization of opposition: it involved the forced displacement of large numbers of people, many of whom could be presented as sympathy-arousing "tribals"; forced relocation could support a radical campaign to stop the dam; local opposition was well organized and led by a charismatic figure (Patkar); the international campaign benefited from unusually energetic and tenacious organizers (first Clark and Oxfam, then Udall and EDF); some Bank staff members and Bank consultants were severe critics of the way the project was being implemented and helped the external critics with inside information; and the local opposition to Narmada began to be noticeable around 1986, just as Polonoroeste was loosing its mobilizatory potential. Finally, location in India helped, because international NGOs

\footnotetext{
${ }^{82}$ In "Sarovar project: India foregoes World Bank aid", Statesman (India), March 31, 1993.

${ }^{83}$ Reported in "India not to seek further WB loan", National Herald (India), March 31, 1993.

${ }^{84}$ Quoted in "The World Bank cuts funds to a dam project in India", The Independent (UK), April 1, 1993. See also Steven Holmes, "World Bank restrictions prompt India to cancel dam project loan", New York Times, 31 March, 1993.
} 
had good access to English-language information and because India's democratic polity and free press allowed opposition. If Narmada had been in China, Indonesia or Turkey it could not have been used as a spearhead.

The question then is not, "What did the Bank do wrong in Narmada that it did not do wrong in other projects?". This is to make the contrast with one line of Bank selfcriticism, which says that Narmada suffered from serious "entry mistakes", such as poor resettlement planning or environmental assessment—with the implication that other Bank projects had better resettlement planning or environmental assessments. ${ }^{85}$ Not necessarily.

What did make Narmada unusual is the timing that put it in a set of "hinge" projects. It was prepared, appraised and approved at about the same time as the Bank introduced quite new directives on "non-economic" criteria-resettlement and environment. These "noneconomic" criteria and directives were stoutly resisted inside the Bank by the operational people, as we have seen, including South Asia Vice President David Hopper. Their resistance, combined with ambiguity about the status of "directives" (as analogous to national laws or aspirational guidelines), allowed the busy project people to continue to prepare the project as they had prepared projects before the resettlement and environmental directives were introduced. And of course "consultation" with people of the valley was entirely neglected, for the Bank did not have any directives enjoining consultation, let alone experience of it.

India's federal structure made the Bank's implementation of these new directives all the more difficult, because resettlement and water fell under the heading of "state" subjects, not central or joint subjects; but the Bank could lend only to the central government, and could approach the state governments only via the central government, which had only limited influence over the states. (Indeed, the central government sometimes tried to get the Bank to put pressure on the states, thinking that the Bank had more leverage than it did.) The same point applies to all federal structures, including Brazil's.

The Bank's own quality control mechanism-review by central departments like the Agriculture and Rural Development Department and the Office of Environmental Affairs-was easily brushed aside. However, Narmada differed from Polonoroeste in that the central departments were much less involved in opposing it than they had been in Polonoroeste. The staff of the Agriculture Department did not raise alarms about it as they had about Polonoroeste, being sympathetic to large-scale irrigation projects.

The big exception was the person in the center whose job it was to look after resettlement, Michael Cernea. That resettlement was the single axis of center-region conflict within the Bank owes much to the combination of dogged Cernea in the center, a strong local resettlement movement on the ground, and later, a powerful international anti-Narmada movement focused on resettlement. Cernea decided in 1983 to draw a line at Narmada and force the South Asia Projects Department to

\footnotetext{
${ }^{85}$ Hans Wyss, "Bankwide lessons learned from the experience with the India Sardar Sarovar (Narmada) project", mimeo, May 19, 1993.
} 
implement what he-with the backing of McNamara and his own Agriculture director — had only recently persuaded the Bank to adopt as a general resettlement policy.

Although at project approval in 1985 and project effectiveness in 1986 there were resettlement and environmental conditions in the loan agreements, few people on the Bank side or the India side thought they were more than cosmetic. Only later, once NGOs began to train their spotlights on resettlement, did operational people inside the Bank start to worry about these things, and then more resettlement than environment.

\section{Lying}

The problem became, "How does the Bank retrofit a project"? A project is in a sense no more than an agreement over the conditions for the use of borrowed funds. Once the agreement has been reached it is deeply problematic for the Bank to say, "Sorry, but our requirements have now changed, so we must change the agreement", or even to say, "Sorry, but we now have to observe these conditions that we all thought we didn't have to, so you must observe them too". Projects are path-dependent; the way they start imparts direction for years later, partly through the expectations of personnel, partly through the irreversibility of certain steps, and partly because the later addition of conditions (an environmental workplan and a slowdown in dam construction until the workplan can be implemented, for example) may entail huge delays to the whole project that need not have occurred had those conditions been met earlier.

Retrofitting is difficult. The effort to do so in Narmada as NGO pressure built up began to produce apparently deceitful behavior on the part of the operational staff. Their logic went like this.

1. We know things are not going well in the project.

2. But do we want to pull out or suspend?

3. No, it is potentially a damn fine project, and things will go better if we are in. Anyway, management would not allow a pull out, for country relations reasons. India is too big a borrower.

4. Therefore we need to justify staying in. The way to do so is to send reports up the hierarchy that things are going well or at least improving, making sure that if anything is said about things not going well the phrasing implies that they are minor or on the way to being fixed.

The trick is to make the aroma of words do the work that the evidence cannot. It is unlikely that anyone connected with Narmada ever said, "India needs this foreign exchange and we need India to borrow; therefore Narmada must go ahead; therefore we say what needs to be said to justify going ahead". Rarely if ever would people admit even to themselves, "This is wrong but we have to say it anyway". Rather the bias to optimism comes in the atmospherics. The staff could report up the hierarchy, 
"The government has committed itself in this period to finish preparing 10 resettlement sites but only two have been done; and the government has failed to implement its policies on compensation"; or it could say, "The government has committed itself to prepare 10 resettlement sites, two have now been completed, another four are being planned, and the government is initiating major improvements in the policy framework". The second version justifies staying in. And a normative justification for going with the second version is always at hand; it says that the Bank should give heavy weight to what is happening at the margin, for the likely future course of events can be read at the margin. This is how the head of the Agriculture Unit in the Delhi office justified his reversal of Scudder's conclusions after the 1989 resettlement mission; Scudder, he said, was talking about the "average" level of performance, whereas he was looking at policy changes and performance "at the cutting edge".

Nevertheless, with Bank management insisting on good news, mission reports based on a few staff members' 3 day trip to a few accessible corners of the valley would seize upon any sign of progress, however small, and inflate it as a turning point. In one case in Maharashtra about 50 households, out of nearly 3000 eligible households, had moved to a resettlement site ( the others had been persuaded not to do so by Medha Patkar). Of those about 30 had been issued with identity cards identifying them as resettlement beneficiaries, a strictly clerical operation of no difficulty. The mission report took the issuing of 30 identity cards out of 50 as a powerful indicator of progress on the ground, and ignored the fact that only 50 out of 3000 households had agreed to move. The mission leader was well aware of the deception. He saw himself as having no choice.

The NGO's information needs were, in a sense, the mirror image of the Bank's. NGOs had whole structures of communication in place just waiting to hear the bad news. Medha Patkar said to the Indian Administrative Service (IAS) officer in charge of Sardar Sarovar resettlement in Maharashtra after 1990 (whose diligence and determination is credited with turning around the resettlement situation there and subsequently lifting him from the Maharashtra resettlement dumping ground to a plum job at the World Bank in Washington), "It is good officers like you who are a problem for us". Likewise the journalists wanted bad news, for bad news makes good copy. The journalists rarely penetrated into the Narmada valley beyond the nearest village to the train from Bombay, where they would talk to a few activists and write about the dire things that were happening-according to the activists.

The lock-in became especially problematic after 1991 when real progress did begin to be made on the ground in Maharashtra (and earlier in Gujarat). By 1992 there was probably as much support among the tribals in favor of resettlement as against the dam. But the NGOs and the newspapers refused to report on this. The Independent Review team, presented with both negative and positive evidence in the field, put in all the negatives and left out most of the positives, in the opinion of the chief resettlement officer in Maharashtra. In particular, the Review team downplayed the strength of the pro-resettlement sentiment among tribals, he said. Meanwhile, all through this period, Bank management grew more and more 
desperate to find good news, and blurred even more the line between actual progress and hoped-for progress.

\section{Why Not Suspend Before 1993?}

One of the great questions about Narmada is why the problems were allowed to fester so long-why the Bank did not step back in the late 1980s, take a fresh look, admit serious problems, and suspend the loan? It is not that the senior managers did not know what was happening. Though the staff glossed the bad news the senior managers did have other sources of information, notably the NGOs. They knew of the gathering transnational NGO campaign and the hearings in the US Congress in 1989.

First, suspension of any project, anywhere, has high transactions costs for the Bank and for the relevant division. Procedures must be gone through that require intensive supervision both before the threat and after the threat in the build up towards the decision of whether to resume or cancel. But divisional supervision budgets are under tight pressure as division chiefs attempt to allocate more resources at the margin for project preparation. This gives them an incentive to shrink from suspension. Few brownie points are to be earned and many to be lost by not bringing the project to the Board.

Second, suspension of a project in India has particularly high costs. India has traditionally been one of the Bank's most valued customers. In Bank-India relations threats of suspension or cancellation are "not part of the tradition", in contrast to some other regions (notably Africa). ${ }^{86}$ Both the Bank and India knew that the whole relationship might be put under strain if Narmada were suspended or cancelled. This became an especially serious consideration around the time of India's macroeconomic crisis in 1991, when the government promised far-reaching liberalization that the Bank was keen to support.

Third, resettlement would be better if the Bank were involved, even if not perfect. Suspension, it was argued, would only hurt the oustees. Could the Bank walk away from the most vulnerable people?

Fourth, the Government of India wanted the Bank to remain involved partly to augment its own limited leverage over the state governments.

Fifth, Sardar Sarovar was just the first of many projects the Bank would be involved in on the Narmada river, helping to grow its lending and its revenue.

Finally, Bank managers came to see Narmada as a test case of the Bank's resolve to stay in the business of infrastructural lending worldwide and to protect its autonomy from NGO incursions. Ernest Stern was well known for stressing that, "The Bank does not cancel because of political pressure". He would tell his subordinates, "Development is a treacherous business. You'll make mistakes. When

\footnotetext{
${ }^{86}$ Wyss, ibid., p. $4-5$.
} 
crises come you just have to hunker down and wait till the storm dies." The whole idea of the Bank doing "Public Relations", courting journalists and NGOs, appalled him. The Bank should be above that level, he said. ${ }^{87}$ And so the bigger the Narmada campaign, the more the rallying cry inside the India Department became, "The storm will pass. We mustn't cave in."

All these factors indicate why the costs of suspension or cancellation looked to be very high and the benefits of staying in very substantial. Moreover, the India Department had what it considered a workable strategy:

1. Focus on Gujarat, the state with the most to gain from the project and the most capable administration, on the assumption that once things are done well in Gujarat this will put pressure on the other states to move as well.

2. Keep the project on a "short leash", with close monitoring of targets.

3. Go for incremental gains rather than insist on blue-prints in advance, on the assumption that, given the long gestation period, incremental gains will eventually add up to large gains. If the incremental approach led the Bank to be out-ofstrict-compliance with some of its directives (for example, on resettlement or environment), too bad for the directives. No project is in full compliance; there are too many directives for full compliance to be realistic.

The Bank's incremental strategy in Narmada represented (in the eyes of both senior managers as well as project staff) the triumph of substance over formality, of realism over idealism.

Like the frog in the heating pot who doesn't realize until too late that the nice warm bath is becoming frog soup, the Bank faced an escalation too gradual for someone to say, "Let's rethink this project". NGO pressure grew by degrees, and the NGOs making the criticism were British rather than American until 1987, therefore more easily ignored. The time to reshape the project was in 1984-1985, before loan approval and loan effectiveness. As the campaign began, the Bank's "shove off" response became something that then had to be defended. By the time the senior managers noticed that the water was very hot, they were becoming World Bank soup.

The high turnover of managers in the India Department during the second half of the 1980 s contributed to their slowness to notice. Each new division chief and department director wanted several months to familiarize himself with the whole portfolio before making major decisions. He was inclined to accept the project as the project people presented it. All the more so because he knew that Ernest Stern, who remained de facto the most powerful person in the Bank even while senior vice president for finance, took a specially protective interest in the Bank's work in India, "his" country. Who in their right mind would go up against Stern if they did not have to?

It is also important that the Bank did not staff up a crisis management team. Even as the Bank as a whole came under sustained attack from the late 1980s through to

\footnotetext{
${ }^{87}$ From a source who worked closely with Stern during this time.
} 
1993 almost nothing special was done inside the Bank to enhance its capacity to respond. With the partial exception of the India Department's environment/ resettlement czar, no senior Bank professional staff was assigned to take charge of the Sardar Sarovar resettlement project component, despite it being so contentious. The Bank at no time tried to get a serious political analysis of what was happening in the valley or in the state governments, relying on the seat-of-the-pants understandings of its own staff. The worse the crisis, the more the director of the India Department and his environment/resettlement czar hunkered down and made the decisions themselves, excluding everyone else in the department and answering only to their own superiors.

Their difficulties were magnified by the fact that relations between the director of the India department, German, and Ernest Stern, American of German origin, were bad to the point that they could not stand to be in the same room together; Blinkhorn and the South Asia vice president had to act as go-betweens. (The director had earlier been the deputy Treasurer of the Bank under Stern as senior vice president for finance, and his Germanic concern for correct procedures had clashed repeatedly with Stern's budget entrepreneurialism. The director had later been chief of staff for Moeen Qureshi when Qureshi was in charge of all Bank operations, which lead him into more fights with Stern.) Moreover, the director and his environment/ resettlement czar had to manage the crisis on top of normal workloads, and with no more than the normal budget for supervision of a project of this size. The thinness of Narmada crisis management is striking testimony to rigid personnel and budgetary systems.

In particular, the Bank did not try to lift decisions about the future of the project out of the hands of those who had a vested interest in continuing. Once it became clear that Bank-wide interests were at stake, the Bank could have appointed a Bankwide panel to take the big decisions about Narmada, reporting directly to the president. It did not. This was not peculiar to Narmada; there were no precedents for such crisis management in the Bank, strange to say. ${ }^{88}$

Only twice did senior management above the level of the South Asian vice president have any "public" involvement in the project, both in 1988. The Qureshi resettlement mission of that year illustrates the problem. Qureshi himself was directly involved in setting the benchmarks against which progress should be judged. But the later judgment of whether the benchmarks had been met sufficiently to justify lifting the threat to suspend was put back entirely within the South Asia vice presidency, in the hands of people who had a vested interest in not suspending.

\footnotetext{
${ }^{88}$ A partial exception was the newly filling Tarbella dam in Pakistan in 1974. When it appeared likely to break, the Bank established a crisis room from where it monitored the situation minute by minute, with direct access to McNamara.
} 


\section{Legacies}

Beyond bad blood and bruised egos, Narmada left several legacies. First, the Bank came to be more accepting of international NGOs as legitimate interlocutors. The growth of powerful NGOs able to get the ear of governments complicated the old theory that the Bank is responsible only to its shareholders and to the relevant government; so NGOs should channel their views via the relevant ED, not direct to management. Narmada demonstrated that the Bank ignored (some) NGOs at its peril. And the Independent Review, by confirming much of what NGOs had been saying about the Bank's performance, helped improve their image from unreliable "crybabies" to sources of expertise, information feedback, and possible political help that the Bank should use. (In Polonoroeste, by contrast, the many NGO criticisms were never brought together in one place and ratified by an independent body.) The Bank moved in this direction to the point where there was by the late 1990s a more routinized, more cooperative, less antagonistic relationship between the Bank and some NGOs than was true earlier.

Second, the Bank came to accept the need to ensure consultation with project affected peoples, often via NGOs. The Independent Review endorsed the idea that much of the mishandling of resettlement and environmental questions in Narmada was due to a lack of consultation with area residents. International NGOs and Part I governments redoubled efforts to get the Bank to insert consultative elements into its project procedures. $^{89}$

Third, the Bank's environmental and especially its social establishment had a boost of legitimacy after the Independent Review's report in 1992. They became the organization's protectors against another Narmada. Country directors and division chiefs who had never before voiced much sympathy for environmental or social concerns began telling their staffs, "We must avoid another Narmada". The director of the India Department, post-Independent Review, kept telling his staff, "This is a changed Bank. We cannot continue to do projects in the old way." Several times he ordered his staff to classify their projects as "A" (environmentally sensitive) even when the regional environment division had agreed on a " $B$ ". The " $A$ " ensured that the project went through a comprehensive environmental review.

Prompted by the Narmada experience the Bank reviewed the resettlement aspects of all projects active, world-wide, for the period 1986 to $1993 .^{90}$ The Bank's resettlement policy became widely known among project staff, as something they could no longer treat casually.

Yet many people in the Bank, including among its senior management, continue to think that the Bank's resettlement policy is, as Ernest Stern put it, "an exaggerated response". He went on, "The condition of equal livelihood in the new place is too

\footnotetext{
${ }^{89}$ See Working With NGOs: A Practical guide to Operational Collaboration Between the World Bank and Nongovernmental Organizations, Operations Policy Department, Washington DC: The World Bank, March 1995.

${ }^{90}$ See Resettlement and Development, Washington DC: World Bank, April 1994.
} 
stringent as a general rule. It is possible where land is abundant and where there is a good financial system (for example Argentina or even Mexico), but almost impossible-I would say impossible — in India and Bangladesh". ${ }^{91}$

Nor does the boost in the legitimacy of environment and resettlement extend to rewarding those who tried to advance environmental and resettlement concerns from within the India Department. On the contrary. Those few people inside the department who became known as project critics have subsequently not been promoted, ${ }^{92}$ while most of those in the direct line of responsibility for Narmada have been promoted. David Hopper, the South Asia vice president throughout the evolution of the project up to 1987, was promoted to senior vice president; his successor as regional vice president in the late 1980s, when the crisis erupted and when things might have been done differently, was promoted to be managing director; the two successive directors of the India department in the late 1980s were promoted to vice president; and the resettlement/environment czar was promoted to division chief.

Finally, the Narmada campaign gave leverage for two accountability reforms in the Bank. It accelerated the already growing pressure for a more liberal information disclosure policy. And it directly catalysed a resolution to establish a permanent inspection panel, which began operating in 1994 and for its first decade of existence was one of the most divisive issues on the Board, generally pitting Part II countries against Part I.

These are legacies within the Bank. On the ground the game described here has continued unabated to this day (meaning the mid to late 1990s). On one side are activists and some federal bodies pressing the courts and multiple review bodies to require that dam construction (especially the height of the dam, which determines the submergence area) must be constrained by progress on resettlement and environmental work; while on the other side are the construction organizations which continue, bulldozer fashion, to build the dam, almost as though the former did not exist. Meanwhile the construction of the distribution system and the drinking water pipelines has hardly begun. S. Parasuraman and colleagues write that "The progress made by the SSP [Sardar Sarovar Project] does not seem to be very different from India's experience with major irrigation and power projects: while main civil works somehow get completed, creation of the necessary infrastructure to realize benefits of the projects remain uncertain". 93

\footnotetext{
${ }^{91}$ Ernest Stern, personal communication, June 1995.

${ }^{92}$ One of India's best known resettlement experts, Abdul Salam, worked as a local consultant on Sardar Sarovar resettlement from 1987 to 1989 . Shortly after the 1989 mission's return to Delhi a meeting was held in the Bank's Delhi office to discuss its findings. Salam informed the meeting that on the basis of what he had seen for the past two years he considered the Bank's resettlement strategy a failure cloaked in hypocrisy. He announced his resignation from further work on Sardar Sarovar resettlement. Thereafter he was not hired by the Bank in any capacity until Cernea hired him to help with the resettlement review in 1993, and by 1996 had never been hired by the India Department. Subsequently, however, he has again been hired by the Bank.

${ }^{93}$ S. Parasuraman, et al., "Sardar Sarovar project: the war of attrition", Economic and Political Weekly, January 30, 2010.
} 
Robert Hunter Wade is professor of global political economy at the London School of Economics and Political Science. He was awarded the Leontief Prize for Advancing the Frontiers of Economic Thought in 2008; and the American Political Science Association's "Best Book in Political Economy, 1989-91", for Governing the Market: Economic Theory and the Role of Government in East Asia's Industrialization (Princeton University Press, 1990, 2004).

His research has focused on the great "Wealth of Nations" question about how capitalisms generate material well-being and power in the world system-with an interest less in models and statistical techniques and more in the culture and "underwear politics" behind the big trends. This has entailed long-term fieldwork in places including Pitcairn Island, Italy, India, Korea, Taiwan, Iceland, and inside the World Bank and IMF. At the World Bank from 1984 to 1988 he worked in the Agriculture and Rural Development Department and then in the Trade Policy Division. In the mid 1990s he wrote "Greening the Bank: the struggle over the environment, 1970-1995", in D. Kapur, et al., 1997, The World Bank: Its First Half Century, Brookings, volume 2. In the late 1990s he worked as consultant to the Inspection Panel on its investigation of the Qinghai irrigation and resettlement project in western China.

$\mathrm{He}$ is the son of a New Zealand diplomat, educated at Wellington College, Otago University, Victoria University, and Sussex University. He has worked at the Institute of Development Studies (Sussex University), the World Bank, US Congress (Office of Technology Assessment), Princeton University (Woodrow Wilson School), MIT (Sloan School), and Brown University (Watson Institute). His many books and articles include Irrigation and Politics in South Korea (1982); Village Republics; The Economic Conditions of Collective Action in India (1988), and "The Strange Neglect of income inequality in economics and public policy (2014)". In 1992, Dr. Wade's book Governing the Market: Economic Theory and the Role of Government in East Asia, was the American Political Science Association's Best Book or Article in Political Economy, and in 2008 he (along with Jose Antonio Ocampo) was awarded the Leontief prize in recognition of his outstanding contribution to economic theory that addresses contemporary realities.

Open Access This chapter is licensed under the terms of the Creative Commons Attribution 4.0 International License (http://creativecommons.org/licenses/by/4.0/), which permits use, sharing, adaptation, distribution and reproduction in any medium or format, as long as you give appropriate credit to the original author(s) and the source, provide a link to the Creative Commons license and indicate if changes were made.

The images or other third party material in this chapter are included in the chapter's Creative Commons license, unless indicated otherwise in a credit line to the material. If material is not included in the chapter's Creative Commons license and your intended use is not permitted by statutory regulation or exceeds the permitted use, you will need to obtain permission directly from the copyright holder.

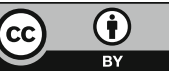

